Studia i Materiały, 2013 (16): 7-32

\title{
Konsumpcja kolaboratywna jako nowy trend konsumencki
}

\author{
Paulina Wardak*, Tomasz Zalega***
}

\begin{abstract}
Celem artykutu jest wykazanie, że młodzi ludzie zamieszkujący duże miasta Polski sa nieufni $w$ stosunku do wspótdzielenia dóbr z nieznajomymi, a co za tym idzie, zdecydowanie chętniej korzystaja z konsumpcji kolaboratywnej, gdy znaja osoby, z którymi dokonuja transakcji. Ponadto $w$ artykule podjęto się próby wykazania, że jednym z kluczowych motywów uczestniczenia mlodych ludzi w konsumpcji kolaboratywnej sq względy finansowe.

Struktura artykutu jest następująca. Po wyjaśnieniu pojęcia konsumpcji kolaboratywnej i jej podstawowych form, skoncentrowano się na omówieniu zjawiska i narzędzi wspierających rozwój konsumpcji wspótpracujacej oraz istoty zaufania do tego alternatywnego trendu konsumenckiego. Po omówieniu metodologii badania oraz krótkim opisie próby badawczej, skoncentrowano się na analizie konsumpcji wspótpracujacej w zachowaniach nabywczych ankietowanych konsumentów, a w szczególności na stosunku ludzi mtodych, zamieszkujących duże miasta Polski, do konsumpcji kolaboratywnej oraz najistotniejszych czynników ksztattujących uczestnictwo respondentów w tym nowym trendzie konsumenckim. Podsumowanie rozważań $i$ ważniejsze wnioski kończa niniejszy tekst.
\end{abstract}

Słowa kluczowe: alternatywne trendy konsumpcyjne, konsumpcja kolaboratywna, gospodarstwa domowe, zachowania konsumpcyjne.

Nadesłany: 9.10.2013 | Zaakceptowany do druku: 25.10.2013

\section{Collaborative consumption as a new consumer trend}

The purpose of this article is to demonstrate that young people living in large Polish cities are distrustful of sharing different goods with strangers, and therefore, they are much more likely to benefit from collaborative consumption when they know the people with whom they make the transaction. Furthermore, the article is an attempt to show that financial reasons are one of the key factors for young people to participate in collaborative consumption. The structure of the article is as follows. The presentation of the concept of collaborative consumption and its basic forms is followed by a discussion about different tools supporting the development of collaborative consumption and the meaning of trust in such an alternative consumer trend. The next section of the article presents research methodology and a brief description of the study sample. Subsequently, the analysis focuses on collaborative consumption in the buying behavior of young people living in big Polish cities and on the most important factors influen-

\footnotetext{
Mgr Paulina Wardak - Grupa Eurocash S.A.

Adres do korespondencji: Grupa Eurocash S.A., ul. Bokserska 66a, 02-690 Warszawa; e-mail: paulina. wardak@gmail.com.

** Prof. UW, dr hab. Tomasz Zalega - Katedra Gospodarki Narodowej, Wydział Zarządzania Uniwersytetu Warszawskiego.

Adres do korespondencji: Wydział Zarządzania Uniwersytetu Warszawskiego, ul. Szturmowa 1/3, 02-678 Warszawa; e-mail: tomasz.zalega@wp.pl.
} 
cing the participation of the respondents in this alternative consumer trend. The article ends with a summary of the discussion and major conclusions.

Keywords: alternative consumer trends, collaborative consumption, households, consumer behavior.

Submitted: 9.10.2013 | Accepted: 25.10.2013

JEL: A12; C18; C46; D03; D12; D18

\section{Wprowadzenie}

Przemiany zachodzące we współczesnym świecie pod wpływem procesów globalizacji i internacjonalizacji gospodarki światowej wywierają istotny wpływ na postawy konsumpcyjne gospodarstw domowych. Zachowania konsumentów na rynku kształtują się pod wpływem wielu determinant, nie tylko stricte ekonomicznych, lecz także społecznych i kulturowych. Z ekonomicznego punktu widzenia, w ekonomii głównego nurtu celem każdego gospodarstwa domowego jest dążenie do realizacji aspiracji konsumpcyjnych w wyniku maksymalizacji oczekiwanej użyteczności z konsumpcji, przy założeniu istnienia zestawu aksjomatów wystarczających do istnienia takiej funkcji. Natomiast $\mathrm{z}$ punktu widzenia czynników pozaekonomicznych (takich jak: wielkość gospodarstwa domowego, cykl życia rodziny, osobowość, styl życia, nawyki, obyczaje, tradycje, naśladownictwo, system wartości), celem konsumentów może być dążenie do osiagnięcia poziomu konsumpcji charakterystycznego dla grup społecznych, do których aspirują (Zalega, 2013a).

W zachowaniach konsumenckich współczesnych gospodarstw domowych na całym świecie można dostrzec pojawienie się nowych trendów konsumenckich. W ramach tendencji bazowych, diagnozowanych pod koniec pierwszej dekady XXI w., wśród „alternatywnych” lub „nowych” trendów konsumenckich wymienia się konsumpcję kolaboratywną, zwaną również konsumpcją współpracującą, sharing'iem, mesh'em lub „ekonomią dzieloną” (Zalega, 2013b, s. 25).

Konsumpcja kolaboratywna jest stosunkowo nowym trendem konsumenckim. Z tego też względu trwają badania, które próbują przybliżyć strukturę i determinanty tego zjawiska. Bez wątpienia, jednym z klu- czowych wydarzeń kształtujących wspomniany alternatywny trend konsumencki jest globalny kryzys gospodarczy oraz intensywny rozwój technologii (Rifkin, 2011). Kluczowymi aspektami w dyskusji nad konsumpcją kolaboratywną są motywy, jakimi kierują się jej uczestnicy oraz ich podejście do nowego trendu konsumenckiego.

Celem artykułu jest wykazanie, że młodzi ludzie zamieszkujący duże miasta Polski są nieufni w stosunku do współdzielenia dóbr $\mathrm{z}$ nieznajomymi, a co za tym idzie, zdecydowanie chętniej korzystają z konsumpcji kolaboratywnej, gdy znają osoby, z którymi dokonują transakcji. Ponadto $\mathrm{w}$ artykule podjęto się próby wykazania, że jednym z kluczowych motywów uczestniczenia młodych ludzi w konsumpcji kolaboratywnej są korzyści finansowe, takie jak np. oszczędność pieniędzy.

Struktura artykułu jest następująca. Po wyjaśnieniu pojęcia konsumpcji kolaboratywnej i jej podstawowych form, skoncentrowano się na omówieniu zjawiska i narzędzi wspierających rozwój konsumpcji współpracującej oraz istoty zaufania do tego alternatywnego trendu konsumenckiego. W dalszej części tekstu, po omówieniu metodologii badań oraz krótkim opisie próby badawczej, skoncentrowano się na analizie konsumpcji współpracującej w zachowaniach nabywczych ankietowanych konsumentów oraz najistotniejszych czynników kształtujących uczestnictwo badanych w analizowanym trendzie konsumenckim. Podsumowanie rozważań i ważniejsze wnioski kończą niniejszy tekst.

\section{Pojęcie konsumpcji kolaboratywnej}

Konsumpcja kolaboratywna zwana także konsumpcją współpracującą jest nowym trendem konsumpcyjnym, który bazuje na pożyczaniu, wymianie, barterze bądź płat- 
nym udostępnianiu swych dóbr innym osobom. Jest to trend stojący w opozycji do dotychczas królującej w społeczeństwach potrzeby posiadania. Konsumpcja kolaboratywna opiera się na idei współdzielenia i tzw. product service approach, czyli skupieniu się na funkcji produktu, bez konieczności posiadania go na własność. Innymi słowy, nie potrzebujemy płyty DVD, tylko filmu, który możemy z niej obejrzeć. Po przeczytaniu książki możemy wymienić ją na inną. Rozwiązania $\mathrm{z}$ nurtu konsumpcji współpracującej sięgają od zwykłej sąsiedzkiej wymiany przysług, przez różnego typu biblioteki, po coraz bardziej rozpowszechnione w Europie rowery miejskie (system, który pozwala mieszkańcom krótkoterminowo korzystać z rowerów ustawionych na specjalnych stanowiskach w wybranych punktach miasta) czy systemy współdzielenia samochodów (np. ZipCar) (Zalega, 2013a). Niewątpliwie, konsumpcja kolaboratywna nie tylko pozwala ograniczyć konsumpcję indywidualna i niepotrzebne zakupy, lecz także wzmacnia integrację i więzi społeczne.

Po raz pierwszy termin ten został użyty w 1978 r. przez amerykańskich profesorów M. Felson oraz J.L. Spaeth w napisanym przez nich artykule „Community Structure and Collaborative Consumption: A routine activity approach". Artykuł dotyczył wypożyczania samochodów innym osobom i został opublikowany w prestiżowym miesięczniku American Behavioral Scientist. Obecnie, pojęcie konsumpcji kolaboratywnej zostało upowszechnione przez brytyjskiego konsultanta ds. zarządzania R. Algara, który w 2007 r. opublikował artykuł „Konsumpcja kolaboratywna” (Collaborative Consumption), zamieszczony w Leisure Report Journal. Natomiast do rozpowszechnienia tego terminu niewątpliwie przyczyniły się R. Botsman i R. Rogers. W 2010 r. obie ekonomistki wydały wspólnie książkę pt. What's Mine Is Yours: The Rise of Collaborative Consumption. Monografia ta jest bardzo wnikliwą analizą zjawiska konsumpcji kolaboratywnej oraz próbą potwierdzenia, że nie jest to jednorazowy alternatywny trend konsumencki, ale długoterminowa rewolucja w sposobie konsumowania. W tym samym czasie ukazała się książka L. Gansky pt. The Mesh: Why the Future of Business is Sharing. W monografii autorka przedstawia konsumpcję kolaboratywną jako zjawisko, które rozwija się w błyskawicznym tempie i zmienia oblicze dotychczasowej konsumpcji. R. Botsman zaprezentowała własny model konsumpcji kolaboratywnej oparty na wieloletnich badaniach, na konferencji $T E D x^{1}$ w Sydney w 2010 r. Konferencja ta została w całości wyemitowana przez ABC Television w programie Big Ideas. Natomiast TIME Magazine, w tym samym roku, uznał konferencje poświęconą konsumpcji kolaboratywnej za jedną z 10 idei, które zmienią współczesny świat. R. Botsman pojawiła się także na spotkaniu TEDGlobal2012², podczas którego zaznaczyła, że zjawisko konsumpcji kolaboratywnej kreuje także nową walutę wymiany na różnych platformach. Tą walutą jest zaufanie i reputacja.

Ponieważ temat konsumpcji kolaboratywnej jest względnie nowy, ilość dotyczących jej publikacji jest ograniczona. Ponadto nie istnieje również jedna, potwierdzona empirycznie teoria, która by opisywała zjawisko konsumpcji alternatywnej. Niewątpliwie wszelkie badania prowadzone w tym zakresie pozwolą na lepsze zrozumienie pojęcia konsumpcji kolaboratywnej oraz jej wpływu na kształt dzisiejszej i przyszłej ekonomii.

\section{Formy konsumpcji \\ kolaboratywnej}

Konsumpcja kolaboratywna rozwija się w bardzo szybkim tempie. W związku z tym, już teraz można wymienić różne jej formy, jakie powstały na przestrzeni zaledwie kilku lat. Większość z nich dotyczy sposobu dzielenia się oraz wymiany dóbr i usług. Jedną z popularnych form konsumpcji kolaboratywnej są tzw. banki czasu (Felson i Speath 1978). Zwykle działają one jako nieformalne instytucje wzajemnej pomocy, wymiany usług pomiędzy członkami określonej społeczności czy serwisy online. Wymiana przebiega bezgotówkowo, co oznacza, że otrzymuje się usługę za usługę, a walutą wymiany jest czas, czyli za $1 \mathrm{~h}$ poświęconą komuś otrzymujemy $1 \mathrm{~h}$ czasu kogoś innego. Użytkownicy banków czasu deklarują jakie usługi mogą zaoferować w określonym czasie i terminie.

Kolejnym często spotykanym modelem konsumpcji kolaboratywnej jest lokalny system wymiany i handlu LETS (Local Exchange Trading Systems). Zazwyczaj są to organizacje zorganizowane przez lokalne społeczności i zarazem przez nie kontro- 
lowane. Opierają się na bazach danych na temat użytkowników, w których można znaleźć takie informacje, jak: oferowane usługi, przedmioty i potrzeby poszczególnych osób oraz ich stan konta. Poprzez te baze ofert i potrzeb ludzie mogą sami kontaktować się ze sobą, proponując współpracę, wymianę i pomoc. Wspiera to również rozwój nowych znajomości w lokalnym społeczeństwie bądź sąsiedztwie. W przypadku tego typu modeli konsumpcji kolaboratywnej, zazwyczaj nie stosuje się standardowych środków płatniczych, takich jak pieniądze. Najczęściej ludzie decydują się na transakcje barterowe, typu „rzecz za rzecz”. Powszechnie znanym modelem współpracy, który sprawdza się również w przypadku konsumpcji współpracującej, jest barter. Jest to forma wymiany bezgotówkowej, typu przedmiot za przedmiot, usługa za usługę. Uczestnicy wymiany ustalają pomiędzy sobą wartość przedmiotów bądź usług tak, aby bilans transakcji był finalnie zerowy.

Ciekawym rozwiazaniem w odniesieniu do konsumpcji kolaboratywnej jest wirtualna waluta zwana Bitcoin. Jest to pierwszy niekontrolowany przez żadną instytucję finansową ani rząd pieniądz cyfrowy. Celem jej powstania było właśnie pominięcie banków i innych instytucji finansowych $\mathrm{w}$ procesie wymiany. W celu przeprowadzenia transakcji, użytkownicy platformy P2P (peer-to-peer) przesyłają je między sobą przez Internet.

Należy wspomnieć, że istnieją różne formy konsumpcji kolaboratywnej, które dotyczą konkretnych przedmiotów bądź usług. Wśród najistotniejszych z nich można wymienić:

- clothswap, toyswap - bezgotówkowa wymiana ubrań lub zabawek;

- cohousing - połączenie zupełnie samodzielnych mieszkań przestrzenią wspólną, użytkowaną przez wszystkich mieszkańców, jaką może być na przykład: kuchnia, pralnia lub plac zabaw;

- couchsurfing - platforma, poprzez która można zaoferować darmowy nocleg ludziom z całego świata bądź znaleźć kogoś, kto przenocuje nas podczas podróży;

- crowdfunding - społeczne zbieranie funduszy na realizację określonego celu, na przykład otworzenie biznesu bądź wydanie książki; osoby, którym pomysł się podoba mogą wspierać pomysłodawcę niewielkimi kwotami;
- coworking - wynajmowanie pomieszczeń, w których można wykonywać swoją pracę; ta forma konsumpcji kolaboratywnej jest bardzo popularna wśród freelancerów oraz osób pracujących zdalnie dla firmy;

- carpooling - współdzielenie jazdy samochodem za opłatą w celu zmniejszenia kosztów dojazdu do celu;

- roomsharing - wynajmowanie swojego pokoju w określonych terminach za pomocą serwisów internetowych, wynajem taki jest zwykle krótkookresowy np. 2-3 dni i najczęściej korzystają z niego turyści.

Konsumpcja kolaboratywna rozwija się bardzo dynamicznie. Powoduje to, że praktycznie $\mathrm{z}$ każdym dniem przybywa jej nowych form. R. Botsman i R. Rogers (2010, s. 45) wyróżniły trzy główne kategorie współkonsumpcji:

1. Systemy usług produktowych, które powstają wówczas, gdy firmy posiadajace wiele produktów decyduja się na ich udostępnianie osobom trzecim za pewną opłatą, np. rowery, panele słoneczne. Ponadto firmy te oferują często całą gamę usług dopasowanych do produktu, który sprzedają, np. serwis. Sprawia to, że cykl życia produktu staje się coraz dłuży, dzięki czemu zyskuje na tym środowisko naturalne.

2. Rynki redystrybucyjne, czyli rynki, na których zainteresowani przekazują sobie używane przedmioty. W zależności od wykorzystywanego modelu biznesowego, transakcje są bezpłatne bądź płatne w różnych formach, np. punktów, monety cyfrowej badź pieniedzy. W ten sposób wspierane jest ponowne użycie produktów, przez co ich cykl życia się ulega wydłużeniu. Redukuje to również liczbę zasobów potrzebnych do ich produkcji oraz ilość odpadów, co pozytywnie wpływa na środowisko naturalne.

3. Collaborative lifestyle, czyli współkonsumowanie jako pewien styl życia. Ta kategoria współkonsumpcji opiera się na czerpaniu niematerialnych korzyści z konsumpcji kolaboratywnej, takich jak np. czas, umiejetności lub miejsce. Dodatkowym profitem jest również tworzenie nowych relacji oraz więzi społecznych. Analizowana kategoria współkonsumpcji może mieć wymiar zarówno lokalny, jak i globalny. 


\section{Zjawiska i narzędzia wspierające rozwój konsumpcji kolaboratywnej}

W książce pt. What's Mine is Yours: The Rise of Collaborative Consumption, jej autorzy omówili stosunkowo nowy socjalnoekonomiczny rodzaj konsumpcji kolaboratywnej. Dość precyzyjnie pokazuje on, jak nowoczesne technologie umożliwiają ludziom kontakt w celu wymiany różnego rodzaju przedmiotów lub usług. Istotne jest wzięcie pod uwagę genezy konsumpcji kolaboratywnej, jaką R. Botsman i R. Rogers stworzyły we wspomnianej książce. Autorki zauważyły, że postępująca cyfryzacja świata sprawia, iż ludzie przestają być biernymi konsumentami. Ponadto, łączność mobilna pozwala na dzielenie się różnego rodzaju treścią i doświadczeniem w czasie rzeczywistym $\mathrm{z}$ dowolnego miejsca na świecie a także posiada zdolność łączenia ludzi. Należy również podkreślić, że R. Botsman i R. Rogers (2010), na podstawie własnych badań i obserwacji dowodzą, że na obecnym etapie konsumpcji kolaboratywnej można wyróżnić cztery kluczowe determinanty napędzające jej rozwój, do których zaliczyły: równowagę w otoczeniu, znaczenie wspólnoty i autentyczności, technologie peer to peer oraz korzyści finansowe.

\subsection{Równowaga w otoczeniu}

Najważniejszą i prawdopodobnie najbardziej potrzebną siłą napędową dla nowego trendu konsumenckiego, jakim jest konsumpcja kolaboratywna, jest coraz większy nacisk na kwestie środowiska naturalnego i jego ochrony. R. Botsman i R. Rogers (2010) użyły, przykładu Wielkiej Pacyficznej Plamy Smierci, aby zilustrować zaniedbanie ludzi w stosunku do negatywnych skutków hiperkonsumpcji. Im więcej się konsumuje, tym więcej dóbr jest wyrzucanych, tworząc zbiorowiska śmieci. Autorki w swojej książce zwracają uwagę, że potrzebna jest zmiana w trendach konsumenckich, która pomoże zachować większą równowagę w środowisku naturalnym, ponieważ zasoby naturalne Ziemi sa zużywane w zastraszającym tempie. R. Botsman i R. Rogers przytaczaja także wiele historii, które ilustrują pozornie nieuniknione efekty hiperkonsumpcji, a następnie przedstawiają jej cztery aspekty o charakterze socjo-demograficznym i psychologicznym. Pierwszym z nich jest tzw. efekt Diderota, który w bardzo logiczny sposób pokazuje spiralę decyzji konsumpcyjnych. Gdy konsumenci nabywają nowy produkt, wówczas stare przedmioty tracą w ich oczach swoją wartość i urok. Wywołuje to u konsumentów dysonans i popycha ich do kolejnych zakupów. Efekt ten wziął swoja nazwę od francuskiego pisarza, który napisał esej na temat nowej jedwabnej szaty, która zmieniła jego życie. Otrzymał ją w prezencie, po czym zauważył, że wystrój jego gabinetu nie jest spójny z nową szatą. Dlatego też zdecydował się na całkowitą zmianę wystroju wnętrza, mimo że wyposażenie pomieszczenia było w bardzo dobrym stanie. Doprowadziło to do powstania efektu spirali niepotrzebnych zakupów, które w konsekwencji doprowadziły do nieodpartej chęci posiadania rzeczy pasujących do siebie. Efektem wspomnianych działań było zadłużenie finansowe pisarza. Należy w tym miejscu nadmienić, że znawca tematu, antropolog G. McCracken (1990, s. 59), ocenia ten esej jako wymowny symbol stosunkowo silnej relacji, jaka zachodzi pomiędzy konsumentem a siła komplementarności nabywanych dóbr. Z kolei ekonomistka i socjolog, J. Schor (2013, s. 17), analizowała wspomniany efekt w innej perspektywie, odnosząc opisaną sytuację do świadomego stanu konsumpcji napędzanej przez niezadowolenie. Natomiast R. Botsman i R. Rogers (2010, s. 32) twierdzą, że zjawisko to jest wzmocnione przez moc perswazji reklamy, a także zaciera granice między tym, czego konsument naprawdę potrzebuje a tym, co chce rzeczywiście posiadać. Niewątpliwie efekt Diderota stwarza sytuację permanentnego nienasycenia, co w konsekwencji powoduje, że konsument nabywa więcej dóbr niż w rzeczywistości potrzebuje.

Kolejny aspekt hiperkonsumpcji można dostrzec w cyklu życia produktu. Wielu współczesnych ekonomistów sugeruje, że konsumenci sa uzależnieni od nowości i nowych produktów. Colin Campbell dowodzi, że jest to dosyć młode zjawisko oraz podkreśla, że starsze pokolenia są nastawione sceptycznie do nowości, podczas gdy cechą młodych pokoleń jest pogoń za nowościami (Botsman i Rogers 2010, s. 33). Dobitnym przykładem tego zjawiska jest sytuacja obserwowana w branży IT. Produkcja nowego urzadzenia (hardware) stymuluje automatyczne powstanie nowego oprogramowania (software). Obserwuje się, że firmy takich formatów, jak Apple czy 
Microsoft, praktycznie co roku emitują nowe, zaktualizowane wersje swoich systemów operacyjnych. Dla konsumentów oznacza to niekończąca się chęć bycia na bieżąco oraz odświeżania i aktualizowania swoich urządzeń, nawet jeżeli nie jest to konieczne. Należy również zauważyć, że konsumpcja kolaboratywna jest wspierana przez dokładnie te same nowe technologie i infrastruktury, które negatywnie wpływają na równowagę w środowisku naturalnym. J. Sterne (2007, s. 31) twierdzi, że zarówno wiedza na temat równowagi środowiskowej, jak i ,zielone technologie" nadal są pomijane w obszarze projektowania nowych rozwiązań dla IT. Natomiast dwa ostatnie aspekty hiperkonsumpcji dotyczą kultury używania kart kredytowych oraz stwarzania konsumentowi możliwości nieograniczonego wyboru, które powoduje ciągłe nienasycenie. R. Botsman i R. Rogers przytaczają w swojej książce wyniki kilku eksperymentów (przeprowadzonych przez profesora psychologii konsumpcji, ekonomistę oraz profesora marketingu). Przeprowadzone doświadczenia wyjaśniają, w jaki sposób korzystanie z kart kredytowych wpływa na postrzeganie wartości produktu. Ludzie, którzy płacą kartami kredytowymi są mniej świadomi transakcji jakiej dokonują, aniżeli ludzie płacący za tę samą rzecz gotówką. Im więcej kredytu na swojej karcie ma konsument, tym większe są jego pozorne możliwości nabywcze. W efekcie konsument więcej zakupuje dóbr i usług, i tym samym - więcej tworzy odpadów. Przy analizowaniu hiperkonsumpcji istotny jest również tzw. paradoks wyboru, występujący we współczesnym społeczeństwie konsumpcyjnym. W ekonomii behawioralnej i eksperymentalnej zakłada się, że zbyt duży wybór, przed jakim stoją konsumenci, jest czynnikiem skutecznie zakłócającym sposób, w jaki zaspokajają odczuwane potrzeby. W momencie, gdy człowiek nie jest zadowolony z zaspokojenia odczuwanych potrzeb i ma jednocześnie dostęp do szerokiej gamy produktów, wydaje mu się, że satysfakcja, jaką osiąga z konsumpcji, jest „o jeden zakup dalej”, co skłania go tym samym do decyzji nabycia kolejnego dobra.

Te cztery aspekty hiperkonsumpcji ewidentnie pokazują, w jaki sposób przemysł reklamowy wykorzystuje swoją moc przekonywania, w celu zacierania granic pomiędzy pragnieniami konsumentów a ich faktycz- nymi potrzebami. Pokazuje także, jak firmy świadomie skracają cykle życia produktów, w jaki sposób kultura używania kart kredytowych znieczula świadomość ludzką dotyczącą wartości przedmiotów i wreszcie, jak paradoks wyboru sprawia, że współczesny konsument jest wiecznie nienasycony w zakresie nabywania dóbr. Wymienione determinanty można uznać za ukryte inicjatory kultury nadmiernego konsumpcjonizmu, które tworzą niezrównoważony świat, naginając kwestie środowiskowe do własnych potrzeb. Z tego też względu pojawiła się potrzeba zaistnienia nowego, bardziej zrównoważonego modelu konsumpcji.

\subsection{Znaczenie wspólnoty i autentyczności}

Kolejną siłą napędzającą konsumpcję kolaboratywną jest odnowienie wiary w znaczenie wspólnoty. Współcześni konsumenci zaczynają coraz częściej dostrzegać drogę do odzyskania wolnego czasu. Czas wolny, który jest pojmowany w literaturze przedmiotu jako czas pozostający człowiekowi po wypełnieniu obowiązków zawodowych, domowych i rodzinnych, a także po zaspokojeniu potrzeb biologicznych wynikających z fizjologii i funkcjonowania organizmu, może być przeznaczany na samodoskonalenie, samokształcenie oraz ożywienie zaniedbanych form kapitału społecznego. Wśród wielu ludzi coraz częściej pojawia się chęć odnalezienia sensu życia oraz nowych sposobów na funkcjonowanie w społeczności. Oczywistym jest fakt, iż ma to ścisły związek z poszukiwaniem przez człowieka autentyczności i celu w życiu.

Ciekawym przykładem powrotu do naturalności i autentyczności jest rosnąca popularność lokalnych produktów oraz bioproduktów. Coraz większym zainteresowaniem cieszą się również miejsca wymiany (zarówno fizyczne, jak i online) różnych dóbr wykonanych ręcznie, w sposób niestandardowy. Nowe nastawienie konsumentów jest tworzone poprzez trzy podstawowe wartości. Pierwszą z nich jest prostota, natomiast kolejną stanowi chęć powrotu do czasów, gdy rynki były lokalne oraz oparte na silnych więziach. Z kolei ostatnim elementem nowego nastawienia konsumentów jest potrzeba identyfikowalności i przejrzystości danych na temat produktu, ponieważ konsumenci chcą dokładnie wiedzieć co kupują, skąd dana rzecz pochodzi i co istotne, w jaki sposób została wyprodukowana. Ponadto, coraz więcej ludzi chce być 
aktywnymi uczestnikami życia, przejmując świadomie kontrolę nad „własnym światem, w którym na co dzień funkcjonują". Dowodzi to jednoznacznie, że coraz więcej współczesnych konsumentów nie chce być biernymi ofiarami hiperkonsumpcji (Botsman i Rogers, 2010, s. 51).

\subsection{Technologie peer-to-peer}

Peer-to-peer jest modelem komunikacji w sieci komputerowej pozbawionej serwera. W sieci tej każdy komputer odgrywa rolę zarówno serwera, jak i klienta. Wszyscy uczestnicy mają identyczne możliwości zapoczątkowania wymiany danych oraz nadawania i odbierania informacji. Niewątpliwie jest to jeden z kluczowych elementów wspierających istnienie i rozwój konsumpcji kolaboratywnej. Ponadto, niezwykle istotną rolę odgrywają obecnie wykorzystywane sieci społeczne oraz nowe technologie. Internet bezpośrednio łączy ludzi jako infrastruktura połączeń online, dlatego funkcjonuje model jeden-do-jednego, bez konieczności angażowania dodatkowej osoby pośredniczącej. Każdy człowiek online jest wolny i może coś sprzedać na Allegro czy tablica.pl, zamieścić filmy na YouTube, czy znaleźć pracę przez Linkedin, Gumtree bądź GoldenLine. Jeszcze nie tak dawno w świecie, w którym technologie peer-to-peer nie istniały, dużo trudniejsze $\mathrm{i}$ bardziej wymagające było nawiązanie kon- taktu z innymi ludźmi, zaprezentowanie im własnego nagrania video, muzyki, CV bądź czegokolwiek innego co nadaje się do zaoferowania innemu człowiekowi.

Obecnie większość smartfonów posiada fabrycznie zainstalowane aplikacje, takie jak Twitter, Facebook oraz Foursquare. Są to platformy, na których użytkownicy mogą się dzielić tym, co w danym momencie robią i gdzie przebywają. R. Botsman, podczas swojego wystąpienia na konferencji TED, na podstawie przeprowadzonych badań stwierdziła, że Internet i łączność mobilna pomogły ludzkości przejść od kultury egocentrycznej do bardziej społecznej, budując cyfrową generację. Zmiana ta jest możliwa ze względu na generacje Y i Z, które dorastają, dzieląc się z innymi swoimi filmami, muzyką, grami komputerowymi, wiedzą lub umiejętnościami. Pokolenie Milenium jest promotorem zmiany z kultury nastawionej na „mnie” do kultury z perspektywą „my” (Botsman i Rogers 2010, s. 53-55).

Zaprezentowane w tabeli 1 przykłady podkreślają filozofię dostępu ludzi do dóbr, zamiast posiadania ich na własność. Internetowe platformy P2P (peer-to-peer) są jednym ze sposobów na ułatwienie dotarcia do towarów i usług, bez konieczności zakupu własnościowego. W ostatnim czasie powstało wiele internetowych biznesów prowadzących innowacyjne platformy, które umożliwiają konsumpcję kolabora-

Tabela 1. Selektywny przegląd start-upów wspierających konsumpcję kolaboratywną

\begin{tabular}{|l|l|l|}
\hline $\begin{array}{c}\text { P2P produkt-serwis } \\
\text { system }\end{array}$ & \multicolumn{1}{|c|}{ Charakterystyka } & \multicolumn{1}{c|}{$\begin{array}{c}\text { Kraj } \\
\text { funkcjonowania }\end{array}$} \\
\hline \multicolumn{3}{|c|}{ Dobra ogólne } \\
\hline Neighborgoods & $\begin{array}{l}\text { dzielenie się przedmiotami, wiedzą w swoim } \\
\text { sąsiedztwie, środowisku lokalnym }\end{array}$ & międzynarodowe \\
\hline Zilok & wypożyczanie sprzętu, przedmiotów online & US, EU \\
\hline Tablica.pl & sprzedaż, wymiana, wypożyczanie dóbr i usług & Polska \\
\hline Bubbler & wymiana przedmiotów i usług online & Polska \\
\hline \multicolumn{1}{|c|}{ P2P wspólna jazda samochodem } \\
\hline Carpooling & dzielenie jazdy samochodem za opłatą & Europa \\
\hline Mitfahrgelegenheit & dzielenie jazdy samochodem za opłatą & Niemcy \\
\hline LiftShare & dzielenie jazdy samochodem za opłatą & UK \\
\hline \multicolumn{4}{|c|}{ P2P wypożyczanie własnego samochodu } \\
\hline RelayRides & wypożyczanie swojego samochodu innym za opłatą & USA \\
\hline Toogethr & wypożyczanie swojego samochodu innym za opłatą & Holandia \\
\hline
\end{tabular}

Źródło: opracowanie własne na podstawie: Botsman i Rogers (2010, s. 53-55). 
tywną. Platformy te ułatwiają udostępnianie i wymianę rzeczy osobistych między osobami fizycznymi. Cześć serwisów działa lokalnie w określonych krajach, a część $\mathrm{z}$ nich funkcjonuje międzynarodowo. Podstawą korzystania z portali jest wystawienie przez konsumenta przedmiotu bądź usługi, które może wykonać i oczekiwanie na kontakt zainteresowanej osoby. Konsument może również sam nawiązać kontakt $\mathrm{z}$ innymi osobami, w celu propozycji wymiany bądź nabycia dóbr i usług oferowanych przez innych użytkowników platformy. Istnieją także serwisy, takie jak np. duński Peerby4, poprzez które konsument wysyła do społeczności lokalnej zarejestrowanej w danym serwisie zapytania dotyczące konkretnego dobra lub usługi. Platformy takie działają tak długo, jak tylko jest ktoś, kto oferuje wymianę, sprzedaż czegoś i ktoś inny tego szuka. Harvardzki profesor Y. Benkler (2004, s. 10) opisal cechy przedmiotów, które z powodzeniem mogą być wymieniane za pomocą systemów P2P (peer-to-peer). Zwrócił uwagę, że dzielone towary są własnością prywatną, natomiast ludzie posiadają ich więcej niż sami są w stanie skonsumować. W efekcie udostępniają je innym, między innymi ze względu na to, że nie używają ich często. Przedmioty te powinny być odpowiednio małe, aby możliwe było ich indywidualne posiadanie dla własnego użytku. W momencie gdy wiele osób jest właścicielem tychże dóbr, w społeczeństwie zaistnieje nadwyżka, którą konsumenci będą chcieli wykorzystać.

Produkt idealny do współkonsumpcji jest zazwyczaj relatywnie drogi oraz stosunkowo rzadko używany przez właściciela (tab. 2). Dobrym tego przykładem jest platforma MuckWork.com, poprzez którą zarówno muzycy, jak i amatorzy wypoży-

Tabela 2. Cechy przedmiotów nadających się do konsumpcji kolaboratywnej

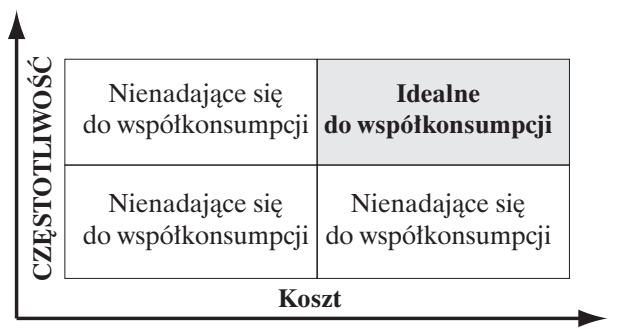

Źródło: opracowanie własne na podstawie: Botsman i Rogers (2010, s. 53-55). czają, za opłatą, swoje instrumenty innym na określony czas. Instrument zwykle jest dosyć drogi i nie jest przedmiotem używanym codziennie, co sprawia, że jest idealnym towarem do wypożyczenia bądź wymiany.

Start-upy, które dotycza konsumpcji kolaboratywnej korzystają z różnych modeli biznesowych. Najczęściej wykorzystywanym modelem jest pobieranie opłaty serwisowej uzależnionej od wartości transakcji wymiany bądź sprzedaży. Opłata za usługę jest oparta na kojarzeniu ze sobą nabywców i sprzedawców bądź wypożyczających i pożyczających. Przykładowo, serwis Airbnb pobiera należność w wysokości 6 do $12 \%$ od całkowitej wartości transakcji. Natomiast platforma Whipcar, poprzez którą ludzie mogą wynajmować samochód w swoim sasiedztwie, wprowadziła opłate dla właścicieli samochodów równą 15\% ceny wynajmu auta. Jest to niezwykle rentowny model biznesowy, ponieważ firma nie ma żadnych zapasów lub kosztów stałych. Główną rolą serwisu jest zapewnienie miejsca na rynku oraz ułatwienie procesu wymiany czy sprzedaży dóbr i usług.

Kolejnym stosowanym rozwiązaniem jest model biznesowy freemium, oferujący podstawowe usługi bądź korzystanie z serwisu za darmo. Natomiast użytkownicy, którzy chcą korzystać z dodatkowych funkcji bądź ekskluzywnych opcji platformy, muszą wykupić specjalny abonament. Zwykle odbiorca ma do wyboru kilka różnych planów abonamentowych, z których może wybrać spełniający jego oczekiwania. Plany te mogą opierać się na ilości pożyczanych dóbr bądź częstotliwości ich udostępniania innym użytkownikom. Przykładowo, francuska platforma Dimdom, zajmująca się wynajmem zabawek, oferuje różne abonamenty: $€ 39,95$ za wypożyczenie pięciu zabawek miesięcznie, zaś €29,95 za pięć zabawek co trzy miesiące. Możliwa jest również kombinacja różnych modeli biznesowych. Tak jest w przypadku holenderskiej platformy OV-bike, która pobiera zarówno stałą opłatę za roczne członkostwo, jak i dodatkowe opłaty naliczane zgodnie z użytkowaniem serwisu.

Jeszcze innym rozwiazaniem biznesowym dla platform P2P (peer-to-peer) jest stosowanie modelu white label. Polega on na dostosowaniu platformy do wymagań klienta i umieszczeniu na produkcie finalnym jego logo, przez co firma tworząca nie 
jest znana użytkownikowi docelowemu. Model ten jest stosowany przez ZimRide, który sprzedaje uczelniom i innym firmom oprogramowanie sieciowe, umożliwiające oferowanie online współdzielenia jazdy samochodem. Następnie klienci ZimRide mogą sami dostosować wygląd platformy do swoich potrzeb i używać jej jako prywatnego narzędzia.

\subsection{Korzyści finansowe}

Kolejnym czynnikiem powodującym wzrost konsumpcji kolaboratywnej jest globalna recesja spowodowana kryzysem gospodarczym, rozpoczętym w 2008 r. Załamanie gospodarcze sprawiło, że ludzie zaczęli zastanawiać się nad swoimi zachowaniami dotyczącymi konsumpcji. Według J. Grahama (2004, s. 204-205), postawy konsumenckie gospodarstw domowych w dobie kryzysu zmieniają się $\mathrm{z}$ egocentrycznych na bardziej nastawione na rodzinę lub społeczność lokalną, ponieważ wzrasta udział decyzji podejmowanych wspólnie przez wszystkich członków gospodarstwa.

R. Botsman i R. Rogers (2010, s. 63) uważają, że w ostatnich dwóch stuleciach świat funkcjonował niczym piramida finansowa, w której ludzie bezwzględnie brali od siebie wzajemnie i od świata, bez zamiaru zwrotu bądź zapłaty. System kapitalistyczny przyniósł co prawda wzrost, rozwój oraz wysoki standard życia oraz innowacje, jednak Ziemia i jej zasoby mocno na tym ucierpiały.

Bezsprzecznie ludzie wysoko cenia łatwy dostęp do dóbr i usług, których potrzebują. Nie mniej jednak, coraz częściej konsumenci decydują się na udział w konsumpcji kolaboratywnej i tym samym rezygnują z posiadania określonych przedmiotów na własność. Światowa recesja gospodarcza spowodowała, że wielu konsumentów borykało się z trudnościami finansowymi, przez co musiało zmniejszyć lub zrezygnować z konsumpcji różnych dóbr i usług. Wtedy też pojawiło się wzmożone zainteresowanie konsumpcją kolaboratywną, dzięki której konsumenci nie muszą rezygnować z danego dobra lub usługi, ponieważ mogą uzyskać do nich dostęp dużo niższym kosztem, niż gdyby je zakupili na własność (Nadjm, 2012; Zalega, 2012b). System ten pozwala zarówno zaoszczędzić, jak i zarobić dodatkowe pieniądze poprzez wymianę jednego dobra na inne bądź wypożyczenie przedmiotów innym za opłatą, np. samochód poprzez serwis RelayRides.

Trend konsumpcji kolaboratywnej rozwija się bardzo intensywnie, stając się tym samym coraz lepszą podstawą do stworzenia rentownego biznesu. Sukcesy takich platform, jak: CouchSurfing, eBay, Carpooling czy ZipCar są tego najlepszym dowodem. Grupa Gartner szacuje, że w 2013 r. rynek $\mathrm{P} 2 \mathrm{P}$ (peer-to-peer) osiagnie wartość 5 miliardów dolarów. Natomiast magazyn Forbes ocenia, że wpływy pieniężne konsumentów z konsumpcji kolaboratywnej przekroczą w tym roku 3,5 miliarda dolarów, wzrastając o 25\% w stosunku do roku 2012 (Castro, 2013). Dowodzi to jednoznacznie, że konsumpcja kolaboratywna jest opłacalna dla wszystkich stron - zarówno dla użytkowników platform, jak i dla ich twórców.

L. Gansky (2010) uważa, że biznes oparty na współdzieleniu pozwala na wykorzystanie marnotrawionych do tej pory zasobów i nadanie im nowej wartości dodanej dla ich posiadacza. Platformy P2P (peer-to-peer) pozwalają na czerpanie korzyści finansowych konsumentom, którzy są właścicielami określonych dóbr. Przykładowo, osoba posiadająca 2 samochody, z których czynnie używany jest tylko jeden, może zaoferować wypożyczanie drugiego auta za opłatą przez serwis internetowy. Tym samym konsument nadal pozostaje właścicielem danego dobra i jednocześnie czerpie dodatkowe korzyści z faktu jego posiadania. Możliwość uzyskania $\mathrm{w}$ ten sposób dodatkowego dochodu jest jednym $z$ ważniejszych determinantów zachęcających do uczestniczenia w konsumpcji kolaboratywnej.

Coraz częściej pojawiają się stwierdzenia, że transakcje, które wymagają udziału pieniędzy nie są współdzieleniem, a zwykłym wynajmem bądź sprzedażą. Amerykański przedsiębiorca E. Griffith (2013) uważa, że nowo powstające platformy P2P zniszczyły pierwotną ideę współdzielenia dla zysku. Ludzie zyskali co prawda możliwość uzyskania dodatkowych korzyści finansowych, jednak nie opiera się to na prawdziwej, bezinteresownej intencji dzielenia się swoją własnością z drugim człowiekiem, szczególnie gdy jest on nieznajomym.

Według raportu stworzonego przez amerykańską firmę konsultingową Latitude i magazyn Shareable na temat konsumpcji kolaboratywnej, konsumenci o relatywnie niskich dochodach rozporządzalnych, zde- 
cydowanie chętniej w niej uczestniczą niż konsumenci zamożni. Ponadto czują się oni bardziej swobodnie, dzieląc swoje rzeczy $\mathrm{z}$ nieznajomymi. Badania nad zachowaniami nabywczymi konsumentów wykazały również, że zdecydowana większość z nich byłaby zainteresowana uczestniczeniem w konsumpcji kolaboratywnej, jeżeli dałoby to możliwość uzyskania dodatkowych środków finansowych (Latitude, 2013).

\section{Konsumpcja kolaboratywna a zaufanie}

Zaufanie można definiować na wiele sposobów. W kategoriach psychologicznych zaufanie jest definiowane jako „całkowite zawierzenie komuś, wiara w kogoś, ufność (Nowy stownik języka polskiego PWN, 2002). Zaufanie można również postrzegać jako swego rodzaju kalkulację (Hardin, 2002), efekt prawidłowej socjalizacji czy społecznego uczenia się (Bandura, 2007). Zdaniem Piotra Sztompki (2007, s. 70), zaufanie jest zakładem podejmowanym na temat niepewnych, przyszłych działań innych ludzi. Z kolei Francis Fukuyama (1997, s. 38), pojmuje zaufanie jako mechanizm oparty na założeniu, że innych członków danej społeczności cechuje uczciwe i kooperatywne zachowanie oparte na wyznawanych normach. Zaufanie ma także wartość pragmatyczną. Definiuje się je wówczas jako „nieformalną normę” zmniejszającą koszty ekonomicznej transakcji, które tworzą nadzór nad zawieraniem kontraktów, rozsązanie sporów i egzekwowanie formalnych porozumień (Inglehart, 1999). Wiele argumentów przemawia za tym, że stanowi ono wartość zdeterminowaną kulturowo, ponieważ jest dziedziczone (Guiso, Sapineza i Zingales, 2008).

Zaufanie może dotyczyć również instytucji, firm lub zasobów Internetu. Niezwykle istotnym tematem jest zarządzanie zaufaniem $\mathrm{w}$ instytucjach wirtualnych, ponieważ zapewnienie odpowiedniego poziomu bezpieczeństwa oraz zaufania pomiędzy jednostkami działającymi w sieci jest bardzo trudne. Pęd za informacją, coraz szybsza wymiana danych, wzrost efektywności działania i rozwój gospodarki w kierunku współzależności i błyskawicznej interakcji powodują, że powstaje coraz więcej przedsiębiorstw działających w sieci, co z kolei powoduje, że konsumenci zaczynają w inny sposób budować swoje zaufanie do określonych organizacji czy nieznajomych osób.

Intensywny rozwój konsumpcji kolaboratywnej wśród konsumentów jest stymulowany przez rosnący wpływ Internetu na ich codzienne życie. Im więcej ludzi ma do czynienia z siecią, tym bardziej postrzegają oni relacje budowane online jako tak samo ważne bądź ważniejsze niż te, które tworzą w życiu realnym (Botsman i Rogers, 2010, s. 92-23).

Nowe pokolenie konsumentów jest przyzwyczajone do obcowania z Internetem przez całe swoje dotychczasowe życie. Nazywane jest pokoleniem Millenium i ma zupełnie inne, nowe spojrzenie na kwestie zaufania oraz współdzielenia dóbr za pomocą Internetu (Botsman i Rogers, 2010, s. 97-98). Zaufanie pomiędzy nieznajomymi, którzy poznają się online permanentnie wzrasta, natomiast maleje zaufanie do dużych korporacji i firm. Dzieje się tak ze względu na błyskawiczny rozwój mediów społecznościowych, jak również globalnej recesji gospodarczej. Według S. Grabner-Krauter (2008, s. 1-20), wzrost zaufania wśród internetowych znajomych ma zasadnicze znaczenie dla pomyślnego rozwoju modelu konsumpcji kolaboratywnej.

\subsection{Znaczenie budowania zaufania dla rozwoju konsumpcji kolaboratywnej}

W przeszłości ludzie budowali swoje zaufanie na bazie kontaktów z przyjaciółmi, rodziną i innymi osobami znanymi w życiu codziennym. Relacje te były rozwijane poprzez ciaggłe interakcje, rozmowy, wzajemną pomoc oraz wsparcie sąsiadów, przyjaciół w ich powszednich zadaniach. R. Putnam (2000) nazywa taki rodzaj relacji „kapitałem społecznym”. Ponadto dowodzi, że obecnie relacje codzienne ludzi są w fazie spadkowej, ponieważ większość społeczeństwa poświęca swój wolny czas na pracę i ciągłe pomnażanie swojego majątku. Poza tym człowiek coraz więcej czasu spędza online przed komputerem i to właśnie tam buduje nowy kapitał społeczny, który jest oparty na zaufaniu do społeczności internetowych.

Wszyscy przedsiębiorcy zajmujący się konsumpcją kolaboratywną zgodnie twierdzą, że budowanie zaufania pomiędzy uczestnikami tego modelu biznesowego jest jedną z najważniejszych kwestii w pro- 
cesie rozwijania biznesu (Gansky, 2012). Znanych jest wiele przypadków nadużyć związanych $\mathrm{z}$ korzystaniem $\mathrm{z}$ platform wspierających konsumpcję kolaboratywną. Jako przykład można podać historię pewnej kobiety, która w czerwcu 2011 r. wynajęła swój dom poprzez serwis Airbnb. Jej dom został splądrowany i okradziony przez najemców. Incydent ten odbił się na reputacji serwisu i sprowokował jego założycieli do wprowadzenia bardziej rygorystycznych środków bezpieczeństwa (poprzez podniesienie gwarancji na wypadek wandalizmu do kwoty $\$ 50$ 000) (Arrington, 2011). Kilka miesięcy po tym zdarzeniu, platforma HiGear wspierajaca wynajem luksusowych samochodów pomiędzy ludźmi, musiała zakończyć swoją działalność, ponieważ skradziono cztery samochody o łącznej wartości \$300 000, które należały do członków serwisu. Doszło do tego pomimo rozbudowanych przez firmę środków bezpieczeństwa, takich jak np. weryfikacja użytkowników, użycie kart kredytowych, ubezpieczenie kolizyjne, depozyt finansowy. Z tego też względu właściciele firmy postanowili, że dalsze jej prowadzenie jest zbyt ryzykowne (Perez, 2012).

Po początkowym okresie wielkiego entuzjazmu, wobec platform konsumpcji kolaboratywnej, przyszedł czas na sceptycyzm wobec modeli biznesowych P2P (peerto-peer). Wzrosły wątpliwości dotyczące poziomu bezpieczeństwa podczas korzystania z serwisów wymiany i udostępniania dóbr online. Jak już wcześniej wspomniano, zaufanie pomiędzy nieznajomymi jest jednym z kluczowych budulców konsumpcji kolaboratywnej. Dlatego też ludzie wybiora współdzielenie dóbr ponad posiadanie i konwencjonalny wynajem tylko w momencie, gdy będzie to odpowiednio bezpieczne (Botsman i Rogers, 2010). Z tego powodu wiele stron internetowych zajmujących się konsumpcją kolaboratywna zaprojektowało mechanizmy budowy zaufania wśród użytkowników. Ułatwiają one tworzenie zaufania w Internecie pomiędzy nieznajomymi, którzy nigdy nie mieli ze sobą kontaktu w świecie realnym.

\subsection{Mechanizmy budowania zaufania}

Budowa idealnego systemu zabezpieczeń dla platform P2P (peer-to-peer) jest olbrzymim wyzwaniem dla przedsiębiorców. Dotychczas powstało wiele narzędzi mają- cych na celu minimalizację ryzyka związanego $\mathrm{z}$ użytkowaniem serwisów wspierających rozwój konsumpcji kolaboratywnej. Mimo to, temat ten jest nadal aktualny i bardzo często poruszany podczas dyskusji o przyszłości modelu współdzielenia dóbr i usług. Ciagle powstaja nowe rozwiązania bezpieczeństwa dla biznesu e-commerce, które po połączeniu ze znanymi elementami mogą stworzyć bardzo ciekawe narzędzia pomiaru reputacji oraz zbierania informacji zwrotnych.

Jednym z najbardziej popularnych mechanizmów, który można znaleźć na wielu platformach $\mathrm{P} 2 \mathrm{P}$ (peer-to-peer), jest możliwość oceny pozostałych użytkowników. Zarejestrowane w serwisach osoby zwykle mogą oceniać pozostałych użytkowników, używając skali od jednego do pięciu (gdzie pięć jest ocena najwyższa, a jeden najniższą). Zaletą tego rozwiązania jest, iż użytkownicy otrzymują oceny wzajemnie od siebie, co niewątpliwie zwiększa ich wiarygodność oraz, że pozostali konsumenci mogą opierać swoje decyzje na czyimś doświadczeniu, ponieważ oceny są publiczne $\mathrm{i}$ widoczne na profilach online. Platformami, na których działa taki mechanizm są na przykład RelayRides oraz Swap. com. Niektóre strony, tak jak np. Airbnb, umożliwiają ocenianie pod względem różnych kryteriów osobno. Na wspomnianej platformie można ocenić zarówno swoje ogólne wrażenie, jak i wyrazić opinię na temat sześciu szczegółowych kategorii. System ten działał świetnie również na eBay, dopóki nie okazało się, że popularny staje się handel „dobrymi ocenami”. Polegał on na tym, że niektórzy producenci zlecali wystawianie pozytywnych ocen pod swoimi produktami. Stworzyło to duże zagrożenie dla rynków bazujących na takich rozwiązaniach, co w efekcie doprowadziło do znalezienia alternatywy.

Kolejnym powszechnie stosowanym rozwiązaniem jest uzupełnianie ocen numerycznych komentarzem bądź opinią na profilu użytkownika. Jest to bardzo dużą zaletą, ponieważ zwykle nie istnieje możliwość poznania w życiu realnym osób z sieci lub jest to bardzo trudne. Dzięki tekstowym opiniom na temat określonych użytkowników, łatwiej jest podjąć decyzję o korzystaniu $\mathrm{z}$ wybranego portalu internetowego. Użytkownicy serwisów internetowych wydają się być bardzo chętni do dzielenia się swoimi doświadczeniami doty- 
czącymi osób bądź usług, z których korzystali. Dodatkowo można także sprawdzić, w ilu transakcjach dana osoba brała udział i jakie są jej poszczególne oceny (pozytywne, negatywne, neutralne). $\mathrm{Z}$ takiego rozwiązania korzystają np. Swap.com oraz CouchSurfing.

Bardzo popularnym narzędziem budowania zaufania jest również synchronizacja platform $\mathrm{P} 2 \mathrm{P}$ (peer-to-peer) z kontami użytkowników w serwisie Facebook. Niewątpliwą zaletą tego rozwiązania jest, że użytkownicy nie muszą tworzyć wszędzie osobnych kont bądź profili, ponieważ mają możliwość logowania się do stron internetowych za pomocą danych wprowadzonych w serwisie Facebook. Czasami wykorzystuje się w tym samym celu synchronizacje z innymi portalami społecznościowymi, takimi jak np. Twitter, Google+, Linkedin. Jest to w pewnym stopniu weryfikacja tożsamości danej osoby oraz zmniejszenie jej anonimowości w sieci. Jest to możliwe, ponieważ Facebook posiada wiele informacji na temat swoich użytkowników, takich jak: zawód, zainteresowania, relacje w jakich sa, informacje o znajomych, zdjecia czy wykształcenie.

Część platform P2P (peer-to-peer) korzysta $\mathrm{z}$ weryfikacji tożsamości osoby za pomoca maila, telefonu oraz danych karty kredytowej. Dzięki takim zabiegom buduje się zaufanie użytkowników oraz zmniejsza ich anonimowość w sieci. Dodatkowym atutem takiej weryfikacji jest fakt, iż dane te sa bardzo personalne i unikatowe, co z kole daje użytkownikom jeszcze więcej pewności o autentyczności drugiej osoby.

Istnieją także certyfikaty potwierdzajace wiarygodność stron internetowych, takie jak: VeriSign Trusted oraz Trusted Site i wiele innych. VeriSign jest certyfikatem dającym użytkownikom platform $\mathrm{P} 2 \mathrm{P}$ (peer-to-peer) poczucie bezpieczeństwa, zaufania, wiarygodności i lojalności. Poza tym platformy P2P coraz częściej wprowadzają także centra zaufania i wsparcia, które są dostępne dla użytkowników przez 24 godziny, 7 dni w tygodniu w celu pomocy użytkownikom, którzy znajdą się w wyjątkowej sytuacji. Takie centrum prowadzone przez serwis Airbnb, zostało uruchomione w odpowiedzi na sytuacje, które przydarzały się subskrybentom strony. Wprowadzanie środków bezpieczeństwa jest ukierunkowane na poprawę wizerunku platform w oczach użytkowników oraz na budowanie ich zaufania oraz przywiązania do serwisów P2P. Mają one zapewniać konsumentów, że platforma, z której korzystają została stworzona przez firme o wysokich kompetencjach, wiarygodności i uczciwości. Przedsiębiorcy zajmujacy sie budowaniem platform P2P dążą do kreowania coraz skuteczniejszych mechanizmów bezpieczeństwa, które pozwolą zwiększyć liczbę zadowolonych użytkowników serwisów.

\section{Konceptualizacja badań}

Konsumpcja kolaboratywna jest nowym i zarazem bardzo interesującym trendem konsumenckim. Dlatego też coraz częściej pojawia się pytanie o to, co głównie motywuje ludzi do uczestniczenia w tym zjawisku oraz jakie znaczenie w tym przypadku mają dla konsumenta korzyści finansowe wynikające $\mathrm{z}$ partycypacji $\mathrm{w}$ transakcjach opartych na współdzieleniu dóbr i usług. Mając to na uwadze, w artykule sformułowano dwie hipotezy główne:

1. Korzyści finansowe sa jednym $z$ głównych czynników, które determinują zaangażowanie młodych ludzi zamieszkujących duże miasta Polski w konsumpcje kolaboratywna.

2. Młodzi konsumenci zamieszkujący duże miasta Polski sa nieufni w stosunku do współdzielenia bądź wymiany dóbr z osobami nieznajomymi.

Sformułowano również trzy hipotezy cząstkowe:

1. Im wyższa jest wartość danego dobra, tym młodzi konsumenci zamieszkujący duże miasta sa mniej chętni do współdzielenia go $\mathrm{z}$ innymi osobami w ramach konsumpcji współpracujacej.

2. Młodzi konsumenci zamieszkujaccy duże miasta Polski sa skłonni uczestniczyć w konsumpcji kolaboratywnej jedynie wówczas, gdy znają ludzi, z którymi będą dokonywać transakcji.

3. W miare poprawy sytuacji finansowej, młodzi konsumenci zamieszkujący wielkie miasta Polski, będą rezygnować z konsumpcji kolaboratywnej na rzecz konsumpcji tradycyjnej.

\subsection{Próba badawcza i jej charakterystyka}

Do przeprowadzenia badań pierwotnych ułożony został kwestionariusz składający się z 21 pytań zamkniętych oraz 8 pytań w metryczce. Na szesnaście pytań zamkniętych należało odpowiedzieć, zaznaczajac jedną $\mathrm{z}$ podanych odpowiedzi, na cztery 
pytania - zaznaczając wszystkie odpowiadające odpowiedzi, natomiast na pozostałe - porządkując odpowiedzi według uznania.

Badanie zostało przeprowadzone poprzez dobór celowo-losowy. Uczestnicy przed przystąpieniem do badania zostali poinformowani o jego celu oraz anonimowym charakterze. Udział w badaniu był bezpłatny. Badanie zostało przeprowadzone w okresie od maja do września 2013 r. Wyniki badania ankietowego zostały poddane analizie statystycznej w programie SPSS for Windows (zgodnie z problematyką badawczą pracy).

W celu osiagnięcia założonych celów, badaniem została objęta próba 162 osób. Uczestniczyły w nim zarówno kobiety (74,7\%), jak i mężczyźni $(25,3 \%)$ z wyraźną dominacją kobiet. Badanie miało zasięg ogólnopolski i zostało przeprowadzone za pomocą ankiety internetowej wśród osób w wieku od 19 do 30 lat, posiadających wyż- sze bądź średnie wykształcenie oraz studiujących lub pracujących.

Zmienna dwumodalna wskazuje na to, iz w grupie badanych dominują osoby mieszkające w miastach liczacych powyżej 500 tys. mieszkańców, z grupy wiekowej 19-25 lat, aktywne zawodowo oraz legitymujące się wykształceniem wyższym.

Prawie 4/5 badanych stanowią osoby w wieku 19-25 lat. Co piąty ankietowany jest $\mathrm{z}$ grupy wiekowej 26-30 lat. Aż 67,9\% respondentów posiada wyższe wykształcenie (magisterskie lub licencjackie), co trzeci zaś legitymuje się wykształceniem średnim. Badanie przeprowadzono wśród respondentów reprezentujących wspomniane grupy wiekowe, ponieważ to one najczęściej aktywnie korzystają z Internetu, przez co mają większe szanse na użycie serwisów P2P (peer-to-peer). Serwisy te wspierają rozwój konsumpcji kolaboratywnej. Według Diagnozy Społecznej 2011, aktywnymi uczestnikami Internetu są głównie ludzie młodzi,

Tabela 3. Płeć respondentów

\begin{tabular}{|l|c|c|}
\hline \multicolumn{1}{|c|}{ Płeć } & Częstość transakcji & Procent odpowiedzi \\
\hline Kobieta & 121 & 74,7 \\
\hline Mężczyzna & 41 & 25,3 \\
\hline Ogółem & 162 & 100,0 \\
\hline
\end{tabular}

Źródło: badanie własne.

Tabela 4. Statystyki opisujące próbę badawczą

\begin{tabular}{|c|c|c|c|c|}
\hline Statystyka & Wiek & Wykształcenie & Status zawodowy & Miejsce zamieszkania \\
\hline Dominanta & $19-25$ & wyższe & pracujący (zatrudniony) & miasto pow. 500 tys. mieszkańców \\
\hline
\end{tabular}

Źródło: badanie własne.

Tabela 5. Wykształcenie i wiek respondentów

\begin{tabular}{|l|c|c|}
\hline \multicolumn{1}{|c|}{ Wyszczególnienie } & Częstotliwość transakcji & Procent odpowiedzi \\
\hline Wiek: & & \\
$19-25$ & 128 & 79,0 \\
$26-30$ & 34 & 21,0 \\
Ogółem & 162 & 100,0 \\
\hline Wykształcenie: & 52 & 32,1 \\
średnie & 110 & 67,9 \\
wyższe & 162 & 100,0 \\
Ogółem & & \\
\hline
\end{tabular}

Źródło: badanie własne.

Wydział Zarządzania UW ～DOI 10.7172/1733-9758.2013.16.1 
Tabela 6. Status zawodowy respondentów

\begin{tabular}{|l|c|c|}
\hline \multicolumn{1}{|c|}{ Status zawodowy } & Częstość transakcji & Procenty \\
\hline Student/uczeń & 59 & 36,4 \\
\hline Pracujący (zatrudniony) & 103 & 63,6 \\
\hline Ogółem & 162 & 100,0 \\
\hline
\end{tabular}

Źródło: badanie własne.

Tabela 7. Miejsce pochodzenia respondentów

\begin{tabular}{|l|c|c|}
\hline \multicolumn{1}{|c|}{ Miejsce pochodzenia } & Częstość transakcji & Procent odpowiedzi \\
\hline Wieś & 28 & 17,3 \\
\hline Miasto poniżej 10 tys. mieszkańców & 8 & 4,9 \\
\hline Miasto 11-50 tys. mieszkańców & 35 & 21,6 \\
\hline Miasto 51-100 tys. mieszkańców & 14 & 8,6 \\
\hline Miasto 101- 500 tys. mieszkańców & 22 & 13,6 \\
\hline Miasto powyżej 500 tys. mieszkańców & 55 & 34,0 \\
\hline Ogółem & 162 & 100,0 \\
\hline
\end{tabular}

Źródło: badanie własne.

w wieku 16-24 lata. Aż 93,1\% badanych z tej grupy wiekowej korzysta aktywnie $\mathrm{z}$ Internetu. Ponadto $88,6 \% \mathrm{z}$ nich legitymuje się wyższym wykształceniem (Diagnoza Spoteczna, 2011).

Ponad 3/5 respondentów pracuje, natomiast niespełna $2 / 5$ ankietowanych posiada status studenta lub ucznia. Jest to istotne z punktu widzenia celów badawczych, ponieważ pozwoli uzyskać odpowiedź na pytanie, czy korzyści finansowe płynące z uczestniczenia w konsumpcji kolaboratywnej są rzeczywiście istotne dla osób posiadających już pewien status społeczny i określony dochód.

Ze względu na fakt, że próba badawcza jest ujednolicona pod względem miejsca zamieszkania, jakim są miasta duże miasta, liczące powyżej 500 tys. mieszkańców, anali- zie poddano również pochodzenie badanych (tab. 7). Najliczniejszą grupę ankietowanych (34\%) stanowią osoby pochodzące $\mathrm{z}$ największych polskich miast. Co piąty ankietowany $(21,6 \%)$ pochodzi z miast liczaccych od 11 do 50 tys. mieszkańców. Natomiast 17,3\% respondentów pochodzi ze wsi.

\subsubsection{Nastawienie ankietowanych konsumentów do konsumpcji kolaboratywnej}

W tej części artykułu zostaną przedstawione najważniejsze statystyki odnoszace się do tych pytań zawartych w ankiecie, które badają nastawienie badanej próby do zjawiska konsumpcji kolaboratywnej.

Pierwsze pytanie, które pojawiło się w kwestionariuszu dotyczy znajomości terminu „konsumpcja kolaboratywna” (tab. 8).

Tabela 8. Czy przed przystąpieniem do wypełnienia ankiety spotkałeś się z terminem „konsumpcja kolaboratywna"?

\begin{tabular}{|c|l|c|c|c|}
\cline { 3 - 5 } \multicolumn{2}{c|}{} & Kobiety & Mężczyźni & Ogółem \\
\hline \multirow{3}{*}{ Tak } & liczebność & 20 & 8 & 28 \\
\cline { 2 - 5 } & procent odpowiedzi & 16,5 & 19,5 & 17,3 \\
\hline \multirow{2}{*}{ Nie } & liczebność & 101 & 33 & 134 \\
\cline { 2 - 5 } & procent odpowiedzi & 83,5 & 80,5 & 82,7 \\
\hline
\end{tabular}

Źródło: badanie własne. 
Wykres 1. Platformy internetowe, z których najczęściej korzystają ankietowani

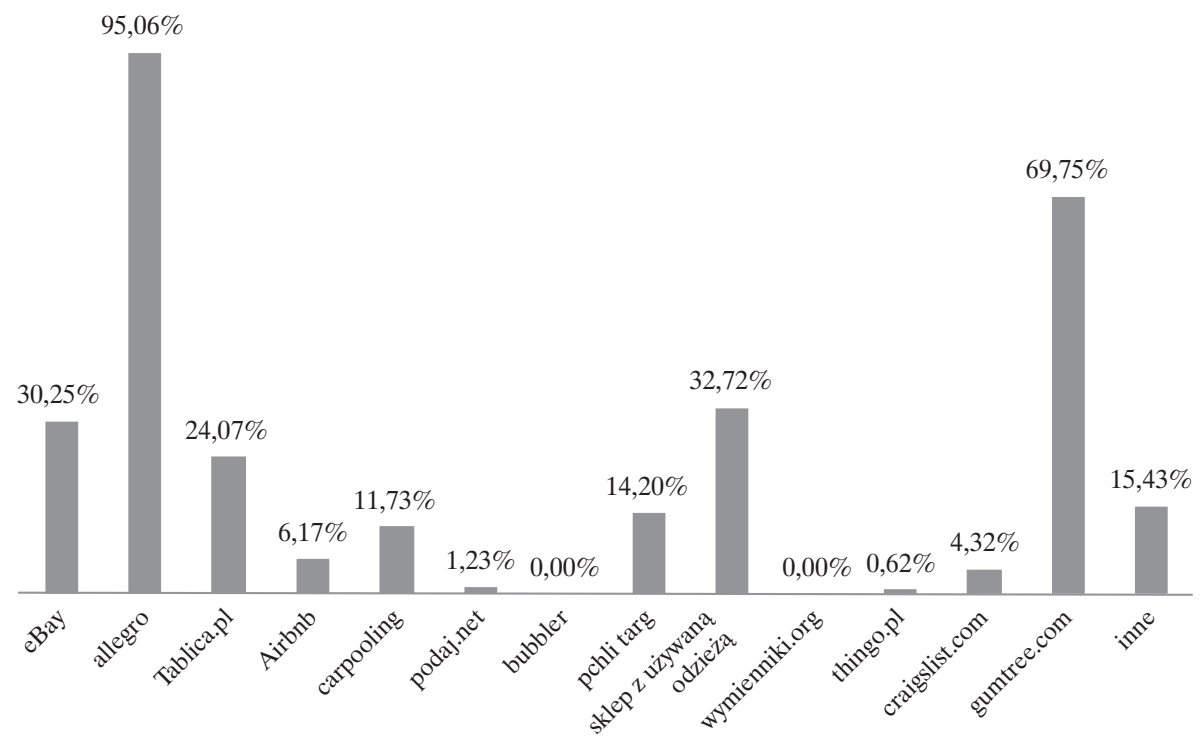

Źródło: badanie własne.

$\mathrm{Z}$ jednej strony, ponad 4/5 respondentów stwierdziło, że nie spotkało się $\mathrm{z}$ terminem „konsumpcji kolaboratywnej” przed przystąpieniem do wypełnienia ankiety. Prawdopodobnie jest to związane z tym, że pojęcie jest względnie nowe. Z drugiej zaś - zdecydowana większość badanych konsumentów korzystała z serwisów internetowych umożliwiających udział w konsumpcji kolaboratywnej (wykres 1).

Aż 95,06\% wszystkich respondentów jako najczęściej używaną przez nich platformę wskazała Allegro, natomiast 69,75\% badanych korzystało z serwisu gumtree. com. Co czwarty ankietowany wskazał na platformę Tablica.pl. Platforma ta wspiera konsumpcję kolaboratywną w wymiarze lokalnym, umożliwiając wymiane badź sprzedaż dóbr pomiędzy sąsiadami. Poza wymienionymi w kwestionariuszu odpowiedziami, respondenci mogli wskazać „inne” serwisy, których używaja. Odpowiedzi takiej udzieliło 15,43\% wszystkich badanych. I tak, najczęściej wymieniane były przez badanych takie serwisy, jak: couchsurfing, freeshop, mensa sight, Facebook, tematyczne fora internetowe, blablacar, hospitality club, swapit.pl, carpooling.

Ponad połowa respondentów wskazała, że ważnym dla nich jest to, aby posiadać wszelkie potrzebne im rzeczy na własność, niezależnie od ich wartości i częstotliwości użytkowania. Może to świadczyć o tym, że przedkładają oni fakt posiadania przedmiotów nad ich rzeczywistą użyteczność. Przypuszczać można, że to właśnie chęć posiadania użytkowanych dóbr jest jednym $\mathrm{z}$ istotnych motywów, którymi kieruja się badani konsumenci, nabywając dobra. Należy również podkreślić, że nie występują w tym przypadku istotne różnice pomiędzy grupą badanych kobiet $(52,1 \%)$ i mężczyzn $(53,7 \%)$.

Ponad $70 \%$ respondentów twierdzi, że problemem jest dla nich pożyczanie rzeczy od nieznajomych osób za pomocą Internetu. Zdecydowanie większy problem ze współdzieleniem posiadanych dóbr oraz pożyczaniem przedmiotów od nieznajomych osób za pośrednictwem Internetu mają kobiety $(73,6 \%)$ niż mężczyźni $(65,9 \%)$. Jest to potwierdzeniem drugiej hipotezy głównej, z której wynika, że młodzi konsumenci zamieszkujący duże miasta niechętnie biorą udział w wymianie dóbr za pośrednictwem Internetu $\mathrm{z}$ nieznajomymi osobami. Taki wynik może być spowodowany tym, iż w dużych miastach anonimowość ludzi jest wysoka, przez co mają oni ograniczone zaufanie do nieznajomych osób. Ponadto świat wirtualny przez wielu jest postrzegany jako mniej wiarygodny niż 
Tabela 9. Chęć posiadania przez badanych użytkowanych dóbr na własność

\begin{tabular}{|l|l|l|l|l|}
\hline \multirow{2}{*}{$\begin{array}{l}\text { Czy jest ważne dla Ciebie, aby posiadać wszelkie potrzebne Ci } \\
\text { rzeczy na własność niezależnie od ich wartości i częstotliwości } \\
\text { korzystania z nich? }\end{array}$} & \multicolumn{2}{|c|}{ Płeć } & \multirow{2}{*}{ Ogółem } \\
\cline { 3 - 5 } & kobiety & mężczyźni & \\
\hline \multirow{2}{*}{$\begin{array}{l}\text { Tak, posiadanie rzeczy na własność jest dla } \\
\text { mnie ważne }\end{array}$} & liczebność & 63 & 22 & 85 \\
\cline { 2 - 5 } & w \% & 52,1 & 53,7 & 52,5 \\
\cline { 2 - 5 } & $\%$ łącznej liczby & 38,9 & 13,6 & 52,5 \\
\hline \multirow{2}{*}{$\begin{array}{l}\text { Nie, wolałbym nie posiadać rzeczy na własnośććn } \\
\text { o ile nie jest to konieczne }\end{array}$} & liczebność & 58 & 19 & 77 \\
\cline { 2 - 5 } & w \% & 47,9 & 46,3 & 47,5 \\
\cline { 2 - 5 } & $\%$ lącznej liczby & 35,8 & 11,7 & 47,5 \\
\hline
\end{tabular}

Źródło: badanie własne.

Tabela 10. Chęć dzielenia się posiadanymi dobrami z innymi ludźmi oraz pożyczanie dóbr od nieznajomych za pomocą Internetu

\begin{tabular}{|l|l|c|c|c|}
\hline \multicolumn{2}{|l|}{$\begin{array}{l}\text { Czy miałbyś problem ze współdzieleniem swoich rzeczy z obcymi } \\
\text { ludźmi bądź pożyczaniem różnych przedmiotów od nieznajomych } \\
\text { za pomocą internetu? }\end{array}$} & \multicolumn{2}{|c|}{ Pleć } & \multirow{2}{*}{ Ogółem } \\
\cline { 3 - 5 } \multirow{2}{*}{$\begin{array}{l}\text { Tak, jest dla mnie problemem współdzielenie } \\
\text { rzeczy z nieznajomymi }\end{array}$} & liczebność & 89 & 27 & 116 \\
\cline { 2 - 5 } & kobiety & mężczyźni & \\
\cline { 2 - 5 } & $\%$ & 73,6 & 65,9 & 71,6 \\
\hline \multirow{2}{*}{$\begin{array}{l}\text { Nie, nie miałbym problemu ze współdzieleniem liczby } \\
\text { swoich rzeczy z nieznajomymi }\end{array}$} & liczebność & 34,9 & 16,7 & 71,6 \\
\cline { 2 - 5 } & w \% & 26,4 & 34,1 & 28,4 \\
\cline { 2 - 5 } & $\%$ lącznej liczby & 19,8 & 8,6 & 28,4 \\
\hline
\end{tabular}

Źródło: badanie własne.

świat realny, dlatego też zaufanie do ludzi poznanych online jest znikome.

Prawie $3 / 5$ respondentów byłoby skłonnych wypożyczać różne przedmioty za pomoca Internetu, ale tylko pod warunkiem, że transakcja będzie zawierana pomiędzy nimi a kimś z sąsiedztwa. Może to oznaczać, że konsumenci darzą większym zaufaniem osoby ze swojego otoczenia niż przypadkowych ludzi poznanych przez Internet. Ponad $57 \%$ badanych wskazało, iż mogłoby wynajać pokój we własnym mieszkaniu osobie, która będzie przebywać w mieście tylko przez kilka dni. Natomiast jedynie co trzeci badany deklaruje chęć uczestnictwa w zamianie domów na określony czas $\mathrm{z}$ nieznajomą osobą. Może to oznaczać, że młodzi konsumenci zamieszkujący duże miasta są bardziej skłonni do uczestnictwa w konsumpcji kolaboratywnej jedynie wówczas, gdy mogą mieć wysoki poziom kontroli nad tym co dzieje się z dobrem, które współdzielą ze nieznajomą osobą. W przypadku wynajęcia na kilka dni pokoju w mieszkaniu, w którym konsument zamieszkuje, poziom ten jest dużo wyższy niż w przypadku udostępnienia całego domu obcej osobie na miesiac. Jedynie $7 \%$ respondentów deklaruje, iż mogłoby wypożyczyć swój samochód nieznajomym za pomoca platformy internetowej. Natomiast $16 \%$ badanych twierdzi, że nie byłoby skłonnych uczestniczyć w żadnej z czterech zaproponowanych form konsumpcji kolaboratywnej (wykres 2). Wyniki te potwierdzają pierwszą hipotezę cząstkową, która dowodzi, iż im wyższa jest wartość danego dobra (np. dom, samochód), tym młodzi konsumenci zamieszkujący duże miasta są mniej chętni do udostępniania go nieznajomym osobom w ramach konsumpcji kolaboratywnej. 
Wykres 2. Chęć korzystania z różnych rodzajów konsumpcji kolaboratywnej

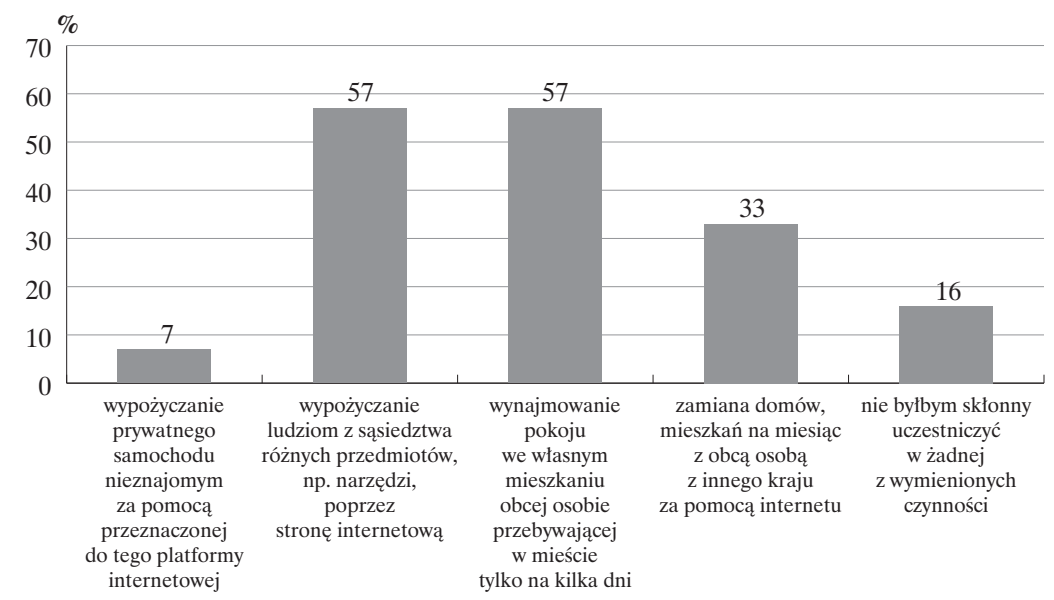

Źródło: badanie własne.

Tabela 11. Uczestnictwo ankietowanych konsumentów w wymianie ubrań, książek, filmów i innych przedmiotów ( $w$ \%)

\begin{tabular}{|l|c|c|c|}
\hline \multirow{2}{*}{$\begin{array}{c}\text { Czy kiedykolwiek uczestniczyłeś w wymianie ubrań, książek, } \\
\text { filmów lub innych przedmiotów? }\end{array}$} & \multicolumn{2}{|c|}{ Płeć } & \multirow{2}{*}{ Ogółem } \\
\cline { 2 - 3 } & kobiety & mężczyźni & \\
\hline $\begin{array}{l}\text { Nie, ale jestem zainteresowany uczestniczeniem w takim } \\
\text { wydarzeniu }\end{array}$ & 44,6 & 41,5 & 43,8 \\
\hline Nie i nie jestem zainteresowany tego typu wydarzeniem & 22,3 & 22,0 & 22,2 \\
\hline Tak & 33,1 & 36,6 & 34,0 \\
\hline
\end{tabular}

Źródło: badanie własne.

Potwierdzeniem tego, że młodzi konsumenci zdecydowanie chętniej współdzielą $\mathrm{z}$ innymi dobra o niższej wartości jest fakt, że prawie $44 \%$ respondentów wyraziła chęć uczestnictwa w wymianie ubrań, ksiażek lub filmów (tabela 9). Z przeprowadzonego badania wynika także, że zaledwie co trzeci ankietowany uczestniczył w tzw. clothswap lub toyswap, czyli w bezgotówkowej wymianie niepotrzebnych ubrań, niechcianych prezentów oraz dziecięcych ubranek, obuwia lub zabawek. Jedynie $22,2 \%$ respondentów nigdy nie uczestniczyło we wspomnianej wymianie i nie jest nią w ogóle zainteresowanych.

W przypadku dóbr, takich jak prywatne mieszkanie lub dom, młodzi konsumenci są sceptycznie nastawieni do ich współdzielenia. Co trzeci badany czułby się niekomfortowo, udostepniajac swoje mieszkanie podróżnikom bądź wynajmując je na week- end nieznajomym za pomoca Internetu. Natomiast prawie połowa respondentów czułaby się niepewnie w takiej sytuacji, jednak jest w stanie rozważyć uczestnictwo w roomsharingu (tab. 12). Jedynie co piaty ankietowany deklaruje uczucie komfortu podczas partycypacji w tego typu konsumpcji kolaboratywnej, przy czym, jedynie $2 \%$ więcej mężczyzn niż kobiet podziela taką opinię.

Młodzi konsumenci w większości $(59,3 \%)$ nie sa zainteresowani współdzieleniem własnego środka lokomocji, jak np. samochód czy motocykl. Niemalże $8 \%$ więcej kobiet niż mężczyzn nigdy nie było użytkownikami platformy carpooling i nie są zainteresowani jej użytkowaniem. Mężczyźni $(34,1 \%)$ są zdecydowanie bardziej zainteresowani dołączeniem do grona użytkowników takiego serwisu internetowego niż kobiety $(25,6 \%)$, mimo że nigdy wcze- 
Tabela 12. Chęć wynajęcia mieszkania/domu nieznajomym osobom za pomocą Internetu (w \%)

\begin{tabular}{|l|c|c|c|}
\hline $\begin{array}{r}\text { Czy czułbyś się komfortowo, uczestnicząc w wymianie domów } \\
\text { bądź zapraszając nieznajomych podróżników na nocleg w prywat- } \\
\text { nym mieszkaniu lub wynajmując własne mieszkanie na weekend } \\
\text { komuś obcemu przez Internet? }\end{array}$ & kobiety & \multirow{2}{|c|}{ mężczyźni } & \multirow{2}{*}{ Ogółem } \\
\hline $\begin{array}{l}\text { Czułbym się trochę niepewnie, ale jestem w stanie rozważyć } \\
\text { uczestnictwo w takich wydarzeniach (w \%) }\end{array}$ & 48,8 & 48,8 & 48,8 \\
\hline Tak, czułbym się komfortowo (w \%) & 20,7 & 22,0 & 21,0 \\
\hline Nie, czułbym się niekomfortowo (w \%) & 30,6 & 29,3 & 30,2 \\
\hline
\end{tabular}

Źródło: badanie własne.

Tabela 13. Częstotliwość korzystania przez ankietowanych konsumentów z carpoolingu (w \%)

\begin{tabular}{|l|c|c|c|}
\hline \multirow{2}{*}{$\begin{array}{c}\text { Czy używasz bądź chciałbyś używać platformy internetowej umoż- } \\
\text { liwiającej współdzielenie samochodu, motocykla lub roweru, jak } \\
\text { np. carpooling? }\end{array}$} & \multicolumn{2}{|c|}{ Płé́ } & \multirow{2}{*}{ Ogółem } \\
$\begin{array}{l}\text { Nie jestem użytkownikiem takiej platformy i nie jestem zaintere- } \\
\text { sowany dołączeniem do niej (w \%) }\end{array}$ & 61,2 & 53,7 & 59,3 \\
\hline $\begin{array}{l}\text { Nie jestem użytkownikiem takiej platformy, ale byłbym zaintere- } \\
\text { sowany dołączeniem do niej (w \%) }\end{array}$ & 25,6 & 34,1 & 27,8 \\
\hline Jestem użytkownikiem takiej platformy (w \%) & 13,2 & 12,2 & 13,0 \\
\hline
\end{tabular}

Źródło: badanie własne.

śniej nie byli jego użytkownikami. Zaledwie $13 \%$ wszystkich respondentów jest użytkownikiem platformy typu carpooling. Wyniki te mogą świadczyć, że konsumenci niechętnie decydują się na współdzielenie własnego środka lokomocji, ponieważ jest on w Polsce w dalszym ciągu dla wielu osób dobrem dosyć drogim,. Wpływ na wyniki ankiety może mieć również i to, że konsumenci na ogół nie mają zaufania do nieznajomych osób poznanych przez Internet. $\mathrm{Z}$ tego też względu nie są zainteresowani udostępnianiem takim osobom wartościowego samochodu.
Zupełnie inaczej wygląda sytuacja w przypadku współdzielenia bądź wymiany różnego rodzaju usług bądź umiejętności z obcymi ludźmi. Analizę takiej sytuacji zawiera tabela 14

Zdecydowana większość młodych konsumentów zamieszkujących duże miasta jest zainteresowana uczestnictwem w wymianie umiejętności typu „bank czasu” z nieznajomymi (tab. 14). Aż 9 na 10 kobiet oraz 8 na 10 mężczyzn jest skłonnych korzystać z platformy umożliwiającej użycie czasu i określonych kwalifikacji jako waluty wymiany. Jedynie $11,7 \%$ respondentów

Tabela 14. Zainteresowanie ankietowanych konsumentów korzystaniem z platformy typu „bank czasu” (w \%)

\begin{tabular}{|l|c|c|c|}
\hline $\begin{array}{r}\text { „Bank czasu” jest platformą pozwalająca używać Twojego czasu } \\
\text { i umiejętności jako waluty. Na przykład możesz zarobić,,godzi- } \\
\text { ny” poprzez uczenie kogoś matematyki, następnie inny użytkow- } \\
\text { nik będzie uczył Ciebie francuskiego w zamian za ,godziny”, } \\
\text { które zarobiłeś wcześniej. Czy byłbyś gotowy uczestniczyć w takiej } \\
\text { wymianie umiejętności? }\end{array}$ & kobiety & mężczyźni & \multirow{2}{*}{ Ogółem } \\
\hline Tak (w \%) & 90,9 & 80,5 & 88,3 \\
\hline Nie (w \%) & 9,1 & 19,5 & 11,7 \\
\hline
\end{tabular}

Źródło: badanie własne. 
nie byłoby gotowych na uczestniczenie we wspomnianym wydarzeniu. Może to świadczyć o tym, że młodzi konsumenci zamieszkujący duże miasta zdecydowanie chętniej biorą udział w konsumpcji kolaboratywnej obejmującej usługi niż dobra materialne o wysokiej wartości.

\subsubsection{Wplyw dochodu na zachowania konsumpcyjne ankietowanych}

W tej części artykułu analizie zostaną poddane zmienne o charakterze nominalnym i porządkowym w celu wykazania istniejących zależności. Przedstawiona zostanie także struktura dochodów respondentów oraz ich indywidualne odczucia odnośnie do sytuacji finansowej, w jakiej się znajdują.

Niemalże 3/4 respondentów zarabia „na rękę" do 3000 PLN miesięcznie. Zdecydowanie więcej kobiet $(34,7 \%)$ niż mężczyzn $(12,2 \%)$ otrzymuje wynagrodzenie wyno- szące poniżej 1000 PLN miesięcznie. Również w grupie dochodowej od 1001 do 2000 PLN dominują kobiety, których jest niemalże o połowę więcej niż mężczyzn. Sytuacja zmienia się wraz ze wzrostem wynagrodzenia. Więcej mężczyzn $(31,7 \%)$ niż kobiet $(18,2 \%)$ posiada miesięczny dochód netto, mieszczący się w przedziale od 2001 do 3000 PLN miesięcznie. Co dziesiąty ankietowany posiada miesięczne zarobki na poziomie od 3001 do 4000 PLN. Jednakże w tej grupie dochodowej nie są widoczne istotne różnice pomiędzy kobietami $(10,7 \%)$ a mężczyznami $(9,8 \%)$. Jedynie $15,5 \%$ ankietowanych zarabia miesięcznie powyżej 4001 PLN. W najwyższej grupie dochodowej dominują zdecydowanie mężczyźni, których jest ponad dwukrotnie więcej niż kobiet. Różnice w dynamice miesięcznych dochodów „na rękę” pomiędzy mężczyznami i kobietami zostały przedstawione również na wykresie 3.

Tabela 15. Sytuacja materialna ankietowanych konsumentów (w \%)

\begin{tabular}{|l|c|c|c|c|}
\hline \multirow{2}{*}{ Ile zarabiasz miesięcznie „na rękę”? } & \multicolumn{2}{|c|}{ Płeć } & \multirow{2}{*}{ Ogółem } & $\begin{array}{c}\text { Procent } \\
\text { skumulowany }\end{array}$ \\
\cline { 2 - 3 } & kobiety & mężczyźni & & 29,0 \\
\hline poniżej 1000 PLN & 34,7 & 12,2 & 29,0 & 29,0 \\
\hline 1001-2000 PLN & 25,6 & 17,1 & 23,5 & 52,5 \\
\hline 2001-3000 PLN & 18,2 & 31,7 & 21,6 & 74,1 \\
\hline 3001-4000 PLN & 10,7 & 9,8 & 10,5 & 84,6 \\
\hline 4001-5000 PLN & 8,3 & 14,6 & 9,9 & 94,4 \\
\hline powyżej 5000 PLN & 2,5 & 14,6 & 5,6 & 100,0 \\
\hline
\end{tabular}

Źródło: badanie własne.

Wykres 3. Różnice w zarobkach ankietowanych kobiet i mężczyzn

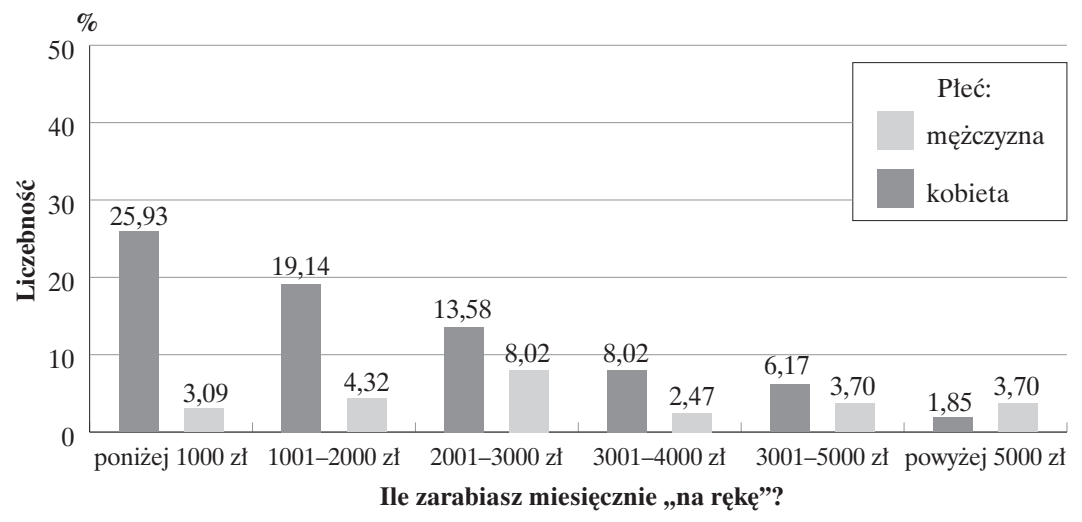

Źródło: badanie własne. 
Tabela 16. Ocena sytuacji finansowej ankietowanych gospodarstw domowych (w \%)

\begin{tabular}{|l|c|c|c|}
\hline \multirow{2}{*}{ Jak oceniasz swoją sytuację finansową? } & \multicolumn{2}{|c|}{ Płeć } & \multirow{2}{*}{ Ogółem } \\
\cline { 2 - 3 } & kobieta & mężczyzna & \\
\hline Bardzo dobra & 5,8 & 12,2 & 7,4 \\
\hline Dobra & 47,9 & 48,8 & 48,1 \\
\hline Średnia & 42,2 & 39,0 & 41,4 \\
\hline Zła & 3,3 & - & 2,5 \\
\hline Bardzo zła & 0,8 & - & 0,6 \\
\hline
\end{tabular}

Źródło: badanie własne.

Kolejną, i to niezwykle istotną informacją, z punktu widzenia uczestnictwa ankietowanych w konsumpcji kolaboratywnej, jest ich subiektywna ocena sytuacji finansowej (tab. 16).

Niemal połowa wszystkich respondentów ocenia swoją obecną sytuację finansową jako dobra. Natomiast 2/5 badanych uważa, że ich sytuacja finansowa jest średnia. W grupie tej przeważają kobiety nad mężczyznami. Natomiast $7,4 \%$ ankietowanych jest zdania, że znajduje się w bardzo dobrej sytuacji finansowej, przy czym, w grupie te jest dwukrotnie więcej mężczyzn niż kobiet. Jedynie 3,1\% ogółu badanych ocenia swoją sytuację finansową jako złą lub bardzo złą. Należy w tym miejscu zaznaczyć, że tak nisko swoją sytuację finansową oceniły wyłącznie kobiety (tab. 16).

Wyniki analizy wynagrodzenia oraz indywidualnej oceny sytuacji finansowej wskazują na to, iż wśród młodych konsumentów zamieszkujących duże miasta, w zdecydowanie lepszej sytuacji finansowej są mężczyźni. Nie dziwi więc fakt, że w odróżnieniu od kobiet, wysoko oceniają oni swoją bieżącą sytuację finansową.

Za najważniejsza korzyść wynikajaca z uczestnictwa w konsumpcji kolaboratywnej respondenci uznali oszczędność pie-

Wykres 4. Korzyści z uczestnictwa w konsumpcji kolaboratywnej

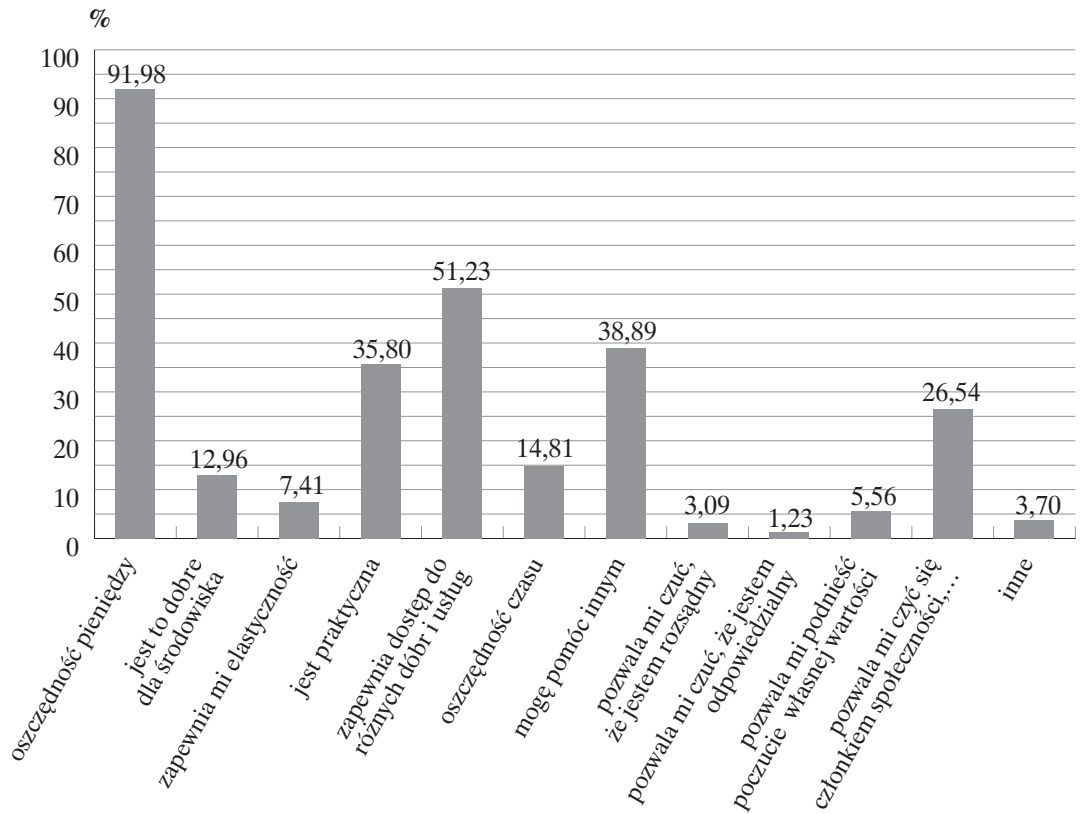

Źródło: badanie własne. 
Wykres 5. Korzyści motywujące ankietowane gospodarstwa domowe do udziału w konsumpcji kolaboratywnej

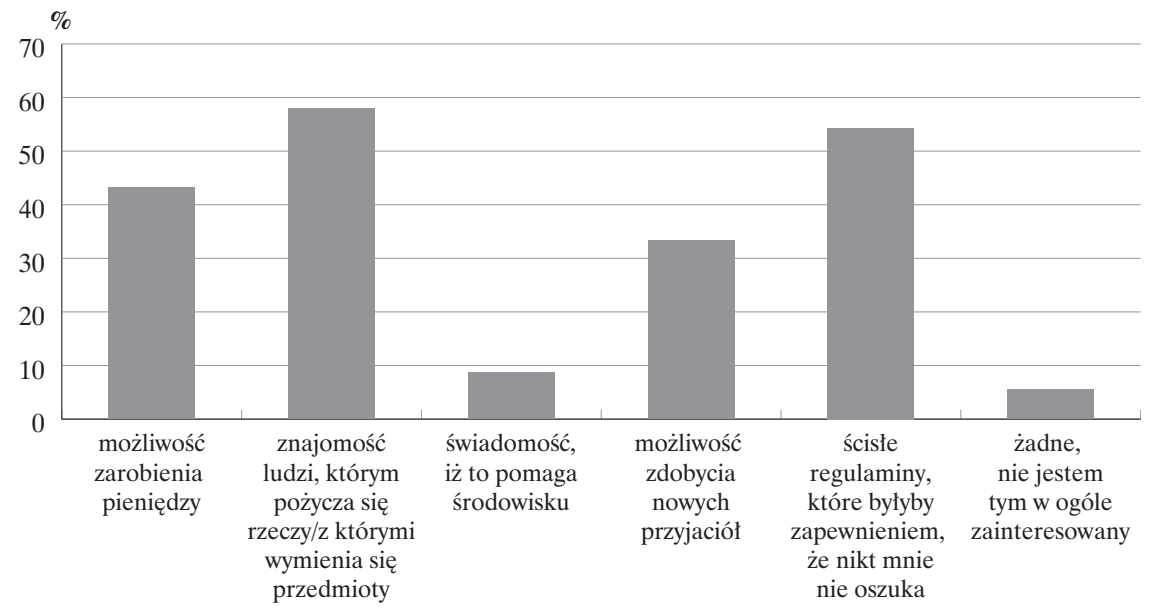

Źródło: badanie własne.

niędzy $(91,98 \%)$. Jest to potwierdzeniem pierwszej hipotezy głównej, która zakłada, iż młodzi konsumenci zamieszkujący duże miasta, decydują się na korzystanie z konsumpcji kolaboratywnej w sytuacji, gdy przynosi im to wymierne korzyści finansowe, takie jak np. oszczędność pieniędzy. Kolejną istotną korzyścią wynikającą z korzystania z konsumpcji współpracującej jest swobodny i niczym nieskrępowany dostęp do różnych dóbr i usług (51,23\% wskazań). Można zatem wnioskować, że konsumenci nie mieli wcześniej dostępu do pewnych dóbr i usług ze względu na ich cenę, ponieważ dobra i usługi, które można nabyć w ramach konsumpcji kolaboratywnej, są ogólnodostępne w kanałach konsumpcji tradycyjnej. W związku z tym prawdopodobne jest, że młodzi konsumenci są skłonni korzystać z konsumpcji kolaboratywnej określonego dobra jedynie wtedy, gdy nie są w stanie nabyć go na własność.

Jako trzy główne korzyści motywujące do udziału w konsumpcji kolaboratywanej za pomocą Internetu, respondenci wskazali na: 1) znajomość ludzi, którym pożycza się rzeczy lub z którymi wymienia się przedmioty;

2) ścisłe regulaminy dające gwarancję bezpiecznego uczestnictwa w konsumpcji;

3) możliwość zarobienia pieniędzy.

Uzyskane na podstawie przeprowadzonego badania odpowiedzi respondentów dobitnie pokazują, że najistotniejszym determinantem motywującym ich do angażowania się w alternatywny trend konsumencki, jakim jest konsumpcja współpracująca, są korzyści finansowe. Potwierdza to jednoznacznie pierwsza hipoteze czastkową. Ponadto uzyskane odpowiedzi potwierdzają słuszność drugiej hipotezy cząstkowej, z której wynika, że młodzi konsumenci zamieszkujący duże miasta są skłonni uczestniczyć we współdzieleniu dóbr i usług tylko wtedy, gdy znają ludzi, z którymi dokonują lub będą w przyszłości dokonywać takich transakcji. Potwierdza to również fakt, iż większość ankietowanych $(54,32 \%)$ jako kluczowy motywator uczestnictwa w konsumpcji kolaboratywnej wskazała istnienie ścisłych regulaminów, gwarantujących bezpieczeństwo zawieranych transakcji sprzedaży bądź wymiany dóbr $\mathrm{z}$ nieznajomymi osobami przez Internet.

Przy założeniu jednakowych kosztów podróży, ponad 3/5 ankietowanych wolałaby zamieszkać w hotelu, aniżeli skorzystać z tzw. roomsharingu. Natomiast w sytuacji, gdy istnieje możliwość zaoszczędzenia połowy kosztów dzięki zamieszkaniu u lokalnej osoby, przeszło 4/5 badanych jest skłonnych zrezygnować $\mathrm{z}$ noclegu w hotelu (tab. 17).

Zdecydowana większość respondentów twierdzi, że budżet domowy, którym dysponują wywiera istotny wpływ na decy- 
Tabela 17. Korzystanie z roomsharingu przez ankietowane gospodarstwa domowe ( $w$ \%)

\begin{tabular}{|l|c|c|c|}
\hline \multirow{2}{*}{$\begin{array}{l}\text { Zakładając, że koszt noclegu byłby ten sam, wolałbyś mieszkać } \\
\text { w hotelu z basenem i restauracją, czy w mieszkaniu nieznanej } \\
\text { Ci osoby? }\end{array}$} & \multicolumn{2}{|c|}{ Płeć } & \multirow{2}{*}{ Ogółem } \\
\cline { 3 - 4 } & kobiety & mężczyźni & \\
\hline W hokalnej osoby (w \%) & 38,8 & 34,1 & 37,7 \\
\hline
\end{tabular}

\begin{tabular}{|c|c|c|c|}
\hline \multirow{2}{*}{$\begin{array}{l}\text { Jeżeli mógłbyś zaoszczędzić połowę kosztów, mieszkając podczas } \\
\text { podróży u lokalnej osoby, wolałbyś zostać w hotelu czy w miesz- } \\
\text { kaniu nieznanej Ci osoby? }\end{array}$} & \multicolumn{2}{|c|}{ Płeć } & \multirow{2}{*}{ Ogółem } \\
\hline & kobiety & mężczyźni & \\
\hline U lokalnej osoby (w \%) & 85,1 & 80,5 & 84,0 \\
\hline W hotelu (w \%) & 14,9 & 19,5 & 16,0 \\
\hline
\end{tabular}

Źródło: badania własne.

zję czy podczas podróży wybierają nocleg w hotelu, czy u osoby wynajmującej pokój w swoim domu/mieszkaniu. Zatem można wnioskować, iż budżet konsumentów jest jednym z kluczowych czynników wpływających na ich decyzje w zakresie korzystania z konsumpcji kolaboratywnej. Natomiast, gdyby budżet nie miał żadnego wpływu na decyzję co do miejsca noclegu w czasie podróży, aż $66,7 \%$ respondentów zamiesz- kałoby w hotelu (tab. 18). Potwierdza to trzecią hipotezę cząstkową, która dowodzi, ze wraz ze wzrostem zamożności konsumentów, zmniejsza się ich zainteresowanie konsumpcją kolaboratywną.

Ponad $70 \%$ respondentów, kierując się pozytywnymi opiniami wystawionymi nieznanej im osobie na platformie internetowej, w celu zarobienia dodatkowych pieniędzy, jest skłonna wynająć na weekend

Tabela 18. Wpływ zamożności ankietowanych gospodarstw domowych na korzystanie z roomsharingu $(w \%)$

\begin{tabular}{|l|c|c|c|}
\hline \multirow{2}{*}{$\begin{array}{c}\text { Czy Twój obecny budżet wpływa na decyzje odnośnie tego czy pod- } \\
\text { czas podróży mieszkasz w hotelu, czy u lokalnej, nieznanej osoby? }\end{array}$} & \multicolumn{2}{|c|}{ Płeć } & \multirow{2}{*}{ Ogółem } \\
\hline Tak, mój budżet wpływa na moją decyzję (w \%) & mężczyźni & \\
\hline Nie, mój budżet nie wpływa na moją decyzję (w \%) & 69,4 & 68,3 & 69,1 \\
\hline $\begin{array}{l}\text { Gdzie mieszkałbyś podczas wyjazdu, gdyby Twój budżet nie wpływał } \\
\text { na tę decyzję? }\end{array}$ & 30,6 & 31,7 & 30,9 \\
\hline U lokalnej, nieznanej osoby (w \%) & 38,8 & 18,8 & 33,3 \\
\hline W hotelu (w \%) & 61,2 & 81,3 & 66,7 \\
\hline
\end{tabular}

Źródło: badania własne.

Tabela 19. Wpływ ocen użytkowników na portalu internetowym a korzystanie przez ankietowane gospodarstwa domowe $z$ roomsharingu ( $w \%$ )

\begin{tabular}{|c|c|c|c|}
\hline \multirow{2}{*}{$\begin{array}{l}\text { Nieznana osoba na platformie internetowej jest oceniania przez } \\
10 \text { innych osób jako dobry i wiarygodny gość. Czy byłbyś skłonny } \\
\text { wynająć tej osobie pokój na weekend w swoim mieszkaniu, aby } \\
\text { zarobić dodatkowe pieniądze? }\end{array}$} & \multicolumn{2}{|c|}{ Płeć } & \multirow[b]{2}{*}{ Ogółem } \\
\hline & kobiety & mężczyźni & \\
\hline Tak (w \%) & 71,1 & 73,2 & 71,6 \\
\hline Nie (w \%) & 28,9 & 26,8 & 28,4 \\
\hline
\end{tabular}

Źródło: badania własne. 
lub krótki okres, jeden $\mathrm{z}$ pokoi w swoim domu/mieszkaniu (tab. 19). Nieco inaczej wygląda sytuacja w przypadku pożyczania od innych użytkowników Internetu rzeczy używanych się okazjonalnie, takich jak np.: namiot, łyżwy, narty.

$\mathrm{Z}$ przeprowadzonego badania wynika, że dokładnie połowa respondentów twierdzi, że woli samemu kupić dobra, których używa w swoim gospodarstwie domowym okazjonalnie. Jednakże więcej mężczyzn niż kobiet jest skłonnych zakupić dobro używane sporadycznie niż pożyczyć je od nieznanych osób za pośrednictwem Internetu. Kobiety postępują racjonalniej i są bardziej skore pożyczyć na pewien okres dobro użytkowane okazjonalnie, aniżeli zakupić je, korzystając z portali internetowych (tab. 20). Zależność pomiędzy sytuacją finansową konsumenta a wpływem jego budżetu na decyzje dotyczące konsumpcji przedmiotów używanych okazjonalnie prezentuje tabela 21 .

Ponad $3 / 5$ respondentów twierdzi, że budżet gospodarstwa domowego wpływa na ich decyzje dotyczące zakupu lub poży- czania dóbr, których używają okazjonalnie. Ponadto wszyscy badani oceniający swoją sytuację finansową jako złą lub bardzo złą twierdzą, że budżet, jakim dysponują jest najistotniejszym determinantem wpływającym na ich decyzje dotyczące podejmowania decyzji konsumpcyjnych. Natomiast w przypadku badanych oceniających swoją sytuację finansowa jako bardzo dobra, prawie $3 / 5$ twierdzi, że budżet nie rzutuje na ich decyzje dotyczącą zakupu bądź wypożyczenia dóbr używanych okazjonalnie. Z kolei gdyby budżet gospodarstwa domowego nie wpływał na decyzje konsumentów odnośnie do zakupu bądź pożyczenia dóbr używanych okazjonalnie, aż $72,2 \%$ respondentów (którzy wskazali we wcześniejszym pytaniu, że budżet którym dysponują wpływa na ich decyzje konsumenckie) twierdzi, że kupiłoby wszystko czego potrzebują. Jedynie $27,8 \%$ badanych (którzy wskazali we wcześniejszym pytaniu, że budżet gospodarstwa domowego wpływa na ich decyzje) deklaruje, że pożyczałoby dobra, z których korzysta okazjonalnie (tab. 21). Z kolei wśród respon-

Tabela 20. Pożyczanie przez ankietowanych rzeczy używanych okazjonalnie od nieznanych osób przez Internet (w \%)

\begin{tabular}{|l|c|c|c|}
\hline \multirow{2}{*}{$\begin{array}{c}\text { Czy byłbyś w stanie pożyczać dobra, których } \\
\text { używasz okazjonalnie od nieznajomych ludzi poprzez Internet? }\end{array}$} & \multicolumn{2}{|c|}{ Płeć } & \multirow{2}{*}{ Ogółem } \\
\cline { 2 - 3 } & kobiety & mężczyźni & \\
\hline Tak, wolę pożyczyć rzeczy, których używam okazjonalnie (w \%) & 51,2 & 46,3 & 50,0 \\
\hline Nie, wolę kupić to czego potrzebuję (w \%) & 48,8 & 53,7 & 50,0 \\
\hline
\end{tabular}

Źródło: badanie własne.

Tabela 21. Wpływ budżetu ankietowanych gospodarstw domowych na decyzje konsumpcyjne (w \%)

\begin{tabular}{|c|c|c|c|c|c|c|}
\hline \multirow{2}{*}{$\begin{array}{l}\text { Czy Twój obecny budżet wpływa na to czy } \\
\text { kupisz, czy pożyczysz dobra, których używasz } \\
\text { okazjonalnie? }\end{array}$} & \multicolumn{5}{|c|}{ Ocena własnej sytuacji finansowej } & \multirow[b]{2}{*}{ Ogółem } \\
\hline & $\begin{array}{c}\text { bardzo } \\
\text { dobra }\end{array}$ & dobra & średnia & zla & $\begin{array}{c}\text { bardzo } \\
\text { zla }\end{array}$ & \\
\hline $\begin{array}{l}\text { Tak, mój budżet wpływa na moją decyzję } \\
(\text { w \%) }\end{array}$ & 41,7 & 56,4 & 74,6 & 100,0 & 100,0 & 64,2 \\
\hline $\begin{array}{l}\text { Nie, mój budżet nie wpływa na moją decyzję } \\
(\mathrm{w} \%)\end{array}$ & 58,3 & 43,6 & 25,4 & - & - & 35,8 \\
\hline \multicolumn{7}{|l|}{$\begin{array}{l}\text { Co zrobiłbyś, gdyby obecny budżet nie był } \\
\text { czynnikiem wpływającym na Twoją decyzję? }\end{array}$} \\
\hline $\begin{array}{l}\text { Pożyczałbym rzeczy, których potrzebuję oka- } \\
\text { zjonalnie (w \%) }\end{array}$ & - & 31,1 & 30,8 & - & - & 27,8 \\
\hline Kupiłbym wszystko, czego potrzebuję (w \%) & 100 & 68,9 & 69,2 & 100 & 100 & 72,2 \\
\hline
\end{tabular}

Źródło: badanie własne.

Wydział Zarządzania UW ～DOI 10.7172/1733-9758.2013.16.1 
Tabela 22. Pożyczanie przez ankietowanych rzeczy używanych okazjonalnie nieznanym osobom przez Internet ( $w$ \%)

\begin{tabular}{|l|c|c|c|}
\hline \multirow{2}{*}{$\begin{array}{l}\text { Jeżeli posiadasz przedmioty, których używasz jedynie okazjonal- } \\
\text { nie, byłbyś skłonny pożyczać je nieznanym osobom poprzez strony } \\
\text { internetowe, aby zarobić dodatkowe pieniądze? }\end{array}$} & \multicolumn{2}{|c|}{ Płé́ } & \multirow{2}{*}{ Ogółem } \\
\cline { 2 - 3 } $\begin{array}{l}\text { Tak, byłbym skłonny pożyczać moje rzeczy, aby zarobić dodatko- } \\
\text { we pieniądze (w \%) }\end{array}$ & 63,6 & 73,2 & 66,0 \\
\hline $\begin{array}{l}\text { Nie, nie byłbym skłonny pożyczać moich rzeczy w celu zarobienia } \\
\text { dodatkowych pieniędzy (w \%) }\end{array}$ & 36,4 & 26,8 & 34,0 \\
\hline
\end{tabular}

Źródło: badanie własne.

dentów, którzy wskazali we wcześniejszym pytaniu, że budżet, którym dysponują rzutuje na ich decyzje konsumpcyjne, wszyscy oceniający swoją sytuację finansową jako bardzo dobrą, złą lub bardzo złą, zakupiliby wszystko czego potrzebują i nie pożyczaliby od innych dóbr, z których korzystaja okazjonalnie. Natomiast zdecydowana większość badanych oceniajacych swoja sytuacje finansowa jako dobrą $(68,9 \%)$ oraz jako średnią $(69,2 \%)$ postąpiła by podobnie. Jest to potwierdzeniem trzeciej hipotezy cząstkowej, która mówi, że w miarę poprawy sytuacji finansowej, konsumenci rezygnują z konsumpcji kolaboratywnej na rzecz konsumpcji tradycyjnej.

Ponad 3/5 respondentów jest skłonnych pożyczać swoje rzeczy nieznajomym osobom przez Internet w celach zarobkowych. W tym przypadku mężczyzn, którzy byliby zainteresowani generowaniem dodatkowego dochodu poprzez pożyczanie przedmiotów jest o ponad $15 \%$ więcej niż kobiet (tab. 22).

\section{Podsumowanie}

Zmiany w zachowaniach nabywczych konsumentów zachodzą powoli, jednakże ich tempo jest silnie uzależnione od czynników: ekonomicznych, politycznych, psychologicznych i socjologicznych. Powstanie konsumpcji kolaboratywnej było stymulowane głównie przez globalny kryzys ekonomiczny oraz intensywny rozwój nowych technologii. Ludzie poszukiwali nowych rozwiazań, które pozwoliłyby im uniknąć drastycznych zmian w dotychczasowym stylu życia, pomimo że znaleźli się w gorszej sytuacji finansowej. W tym samym czasie nastapił intensywny rozwój mediów społecznościowych, który przyśpieszył i zarazem ułatwił kontakt pomiędzy ludźmi z całego świata, a także stał się wzorem dla wielu platform P2P (peer-to-peer).

Wymienione determinaty nie są wystarczające, aby nowy trend konsumencki, jakim jest konsumpcja kolaboratywna, w długim okresie przestał być trendem, a stał się pewnym standardem wśród wszystkich konsumentów. W tym celu na świecie musiałyby zajść nie tylko zmiany ekonomiczne, lecz także polityczne, które zachęcałyby do aktywnego uczestniczenia w konsumpcji kolaboratywnej. Jednak wydaje się to być niewykonalnym, dopóki poziom konsumpcji społeczeństwa oraz PKB są jednymi z głównych wskaźników siły ekonomicznej państw, podczas gdy konsumpcja współpracująca nie wspiera konsumpcji tradycyjnej i nabywania nowych dóbr na własność.

Z przeprowadzonych badań wynika, że ponad $90 \%$ respondentów uważa, że najważniejszą korzyścią wynikającą z uczestnictwa w konsumpcji kolaboratywanej jest oszczędność pieniędzy i możliwość dodatkowego zarobku. Ponadto analizując zachowania konsumentów odnośnie do wplywu budżetu na zachowania konsumpcyjne, zauważono, że większość respondentów zdecydowałaby się nabywać dobra zamiast je pożyczać, gdyby nie byli ograniczeni przez własny budżet. Otrzymane wyniki potwierdziły również trafność założenia, z którego wynika, że im wyższa jest wartość danego dobra, tym młodzi konsumenci zamieszkujący duże miasta Polski są mniej chętni do współdzielenia go z innymi osobami w ramach konsumpcji kolaboratywnej. Zdecydowanie więcej respondentów zaangażowałoby się w konsumpcję współpracującą w zakresie wymiany książek $\mathrm{i}$ innych małych przedmiotów niż 
w wymianę domów bądź wypożyczanie prywatnego samochodu innym nieznanym osobom. Ponadto wszyscy badani oceniający swoją sytuację finansową jako złą bądź bardzo złą stwierdzili, że gdyby budżet gospodarstwa domowego nie wpływał na ich decyzje konsumpcyjne, zdecydowali by się za zakup wszystkiego czego potrzebują. Oznacza to, że w miare poprawy sytuacji finansowej młodzi konsumenci zamieszkujący duże miasta Polski są skłonni rezygnować z konsumpcji kolaboratywnej na rzecz konsumpcji tradycyjnej.

W badaniu zidentyfikowano także fakt, z którego wynika, że zdecydowana większość respondentów ma problem z pożyczaniem rzeczy od nieznajomych za pomoca Internetu. Dowodzi to jednoznacznie, że istnieje istotna potrzeba stworzenia nowych i zarazem skuteczniejszych mechanizmów budowania zaufania pomiędzy wszystkimi stronami zaangażowanymi w konsumpcję kolaboratywną. Badani potwierdzili również, że chętniej będą korzystali z konsumpcji współpracującej, jeżeli będą znali osobę, z którą dokonują transakcji, a także gdy powstaną odpowiednio ścisłe regulaminy zapewniajace im poczucie bezpieczeństwa $\mathrm{w}$ trakcie dokonywania takich transakcji.

Z przeprowadzonego badania wynika, że termin „konsumpcja kolaboratywna” nie jest znany wśród młodych konsumentów zamieszkujących duże miasta Polski. Pomimo tej niewiedzy, większość $\mathrm{z}$ badanych brała udział w różnych wydarzeniach z zakresu konsumpcji kolaboratywnej, kierując się przy tym głównie względami ekonomicznymi.

Konstatując, można powiedzieć, że przeprowadzone badania pozwoliły na wyróżnienie kilku istotnych czynników kształtujących konsumpcję kolaboratywną oraz zaangażowanie konsumentów w stosunku do nowego trendu konsumenckiego.

\section{Przypisy}

1 TEDx - konferencja naukowa TED (Technology, Entertainment and Design) zorganizowana niezależnie oraz lokalnie; podlegająca regułom modelowej konferencji TED organizowanej przez agencję Sampling Foundation.

2 TEDGlobal2012 - globalna konferencja naukowa organizowana przez amerykańską fundację Sampling Foundation; spotkanie to ma na calu rozpowszechnianie idei wartych uwagi z zakresu nauki, techniki, kultury.

\section{Bibliografia}

Arrington, M. (2011). The moment of truth for airing as user's home is utterly trashed TechCrunch. Pobrano z: http://techcrunch.com/.

Bandura, A. (2007). Teoria spotecznego uczenia sie. Warszawa: WN PWN.

Botsman, R. i Rogers, R. (2010). What's Mine Is Yours: The Rise of Collaborative Consumption. New York: Harper Collins.

Benkler, Y. (2004). Sharing nicely: on shareable goods and the emergence of sharing as a modality of economic production, Yale Law Journal, 114

Castro, S. (2013). The new economic model: Collaborative Consumption and the Sharing Economy. Pobrano z: http://www.text100.com/hypertext/2013/06/sharingeconomy/.

Felson, M. i Spaeth, J.L. (1978). Community Structure and Collaborative Consumption: A routine activity approach, American Behavioral Scientist, 21 (March-April).

Fukuyama, F. (1997). Zaufanie. Kapitat spoteczny a droga do dobrobytu. Warszawa: WN PWN.

Gansky, L. (2010). The Mesh: Why the Future of Business Is Sharing. New York: Penguin Books.

Griffith, E. (2013). Does money taint the sharing economy?. Pobrano z: http://pandodaily.com/2013/03/14/ does-money-taint-the-sharing-economy/.

Grabner-Krauter, S. i Kaluscha, E.A. (2008). Consumer Trust in Electronic Commerce: Conceptualization and classificiation of trust building measures. W: T. Kautonen, H. Karjaluoto (red.), Trust and New Technologies: Marketing and Management on the Internet and Mobile Media. London: Edward Elgar Publishing.

Graham, J., (2010). Critical Thinking in Consumer Behavior: Cases and Experiential Exercises. New Jersey: Prentice Hall.

Guiso, L., Sapienza, P. i Zingales, L. (2008). Social capital as good culture, Journal of the European Economic Association, 6(2-3).

Hardin, R. (2009). Zaufanie. Warszawa: Wydawnictwo Sic!

Inglehart, R. (1999). Trust, well-being and democracy. W: M.E. Warren (red.), Democracy and trust. New York: Cambridge University Press.

Latitude, M. (2013). The new sharing economy. Pobrano z: http://latdsurvey.net/pdf/Sharing.pdf.

McCaren, G. (1990). Culture and Consumption. Indiana U.S.A.: Indiana University Press.

Nadjm, M. (2012). Collaborative Consumption - Could Your Business Benefit from Crowd Power?. Pobrano z: http://socialmediatoday.com/ node/758786.

Nowy stownik języka polskiego PWN (2002) (oprac. zbior.). Warszawa: WS PWN. 
Perez, S. (2012). Luxury car-sharing service HiGear shuts down due to theft. TechCrunch. Pobrano z: http://techcrunch.com/.

Putnam, R. (2000). Bowling Alone: The Collapse and Revival of American Community. New York: Simon \& Schuster.

Rifkin, J. (2011). The Empathic Civilization. The Race to Global Consciousness in Word of Crisis. Cambridge: Polity Press.

Schor, J. (2013). Climate Responsibility and New Cultures of Consumption. Pobrano z: http://news. holycross.edu/blog/2013/04/17/juliet-schor-climateresponsibility-and-new-cultures-of-consumption/.

Sterne, J. (2007). Out with the Trash: On the Future of New Media. U.S.A.: University of Minnesota Press.
Sztompka, P. (2007). Zaufanie. Fundament spoteczeństwa. Kraków: Wydawnictwo Znak.

Zalega, T. (2012a). Konsumpcja $w$ wielkomiejskich gospodarstwach domowych $w$ Polsce $w$ okresie kryzysu finansowo-ekonomicznego. Warszawa: Wydawnictwo Naukowe WZ UW.

Zalega, T. (2012b). Konsumpcja. Determinanty, teorie i modele. Warszawa: PWE.

Zalega, T. (2013a). Nowe trendy i makrotrendy w zachowaniach konsumenckich gospodarstw domowych na świecie w XXI wieku, Konsumpcja i Rozwój, 2(5).

Zalega, T. (2013b). Nowe trendy w zachowaniach konsumpcyjnych miejskich gospodarstw domowych w okresie kryzysu, Marketing $i$ Rynek, 8. 